\title{
Leven Star deposit: an example of Middle to Late Devonian intrusion-related gold systems in the western Lachlan Orogen, Victoria
}

\author{
R. R. WHITTAM ${ }^{1}$, F. P. BIERLEIN ${ }^{1,2 \star}$ AND S. MCKNIGHT ${ }^{3}$ \\ 'School of Geosciences, Monash University, PO Box 28E, Melbourne Vic. 3800, Australia. \\ ${ }^{2}$ Tectonics Special Research Centre, School of Earth \& Geographical Sciences, University of Western Australia, \\ 35 Stirling Highway, Crawley, WA 6009, Australia. \\ ${ }^{3}$ School of Science \& Engineering, University of Ballarat, PO Box 663, Ballarat Vic. 3353, Australia.
}

\begin{abstract}
This study documents an example of atypical gold mineralisation in the central Victorian gold province of the western Lachlan Orogen, Australia. Unlike the vast majority of orogenic gold deposits in this region, the Leven Star deposit at Malmsbury is characterised by a disseminated stockwork style of mineralisation, a close spatial and temporal association with post tectonic felsic intrusions, complex alteration characteristics and a $\mathrm{Au} \mathrm{As} \mathrm{Sb}( \pm \mathrm{Bi} \mathrm{Te} \mathrm{Cu} \mathrm{Zn} \mathrm{Pb} \mathrm{Sn} \mathrm{W}$ ) ore assemblage. In contrast to orogenic style, metamorphism related gold mineralisation (ca $440 \mathrm{Ma}$ ), which pre dated magma tism in the western Lachlan Orogen by tens of millions of years, ore formation in the Leven Star deposit was synchronous with, and is paragenetically younger than, Middle to Late Devonian (ca 370 Ma) magmatism. On the basis of these timing relationships, as well as whole rock geochemistry, and structural, petrographic and fluid inclusion data, it is suggested that the Leven Star deposit is not orogenic in character and instead should be classified as intrusion related.
\end{abstract}

KEY WORDS: central Victorian gold province, Devonian, fluid inclusions, gold deposits, Lachlan Orogen, Leven Star, mineralisation.

\section{INTRODUCTION}

The Palaeozoic western Lachlan Orogen is host to one of the world's major gold provinces. The majority of production from primary mineralisation in the central Victorian gold province originates from quartz veinhosted, orogenic 'gold-only' deposits that formed synchronously with regional metamorphism and deformation (Phillips \& Hughes 1996). This orogenic style of mineralisation is historically considered to be the only significant source of gold in the western Lachlan Orogen. In this study, we describe an atypical example of a genetically, temporally and geochemically distinct style of polymetallic gold mineralisation. The Leven Star deposit exhibits numerous similarities with shallow-level intrusion-related gold systems (Lang \& Baker 2001) and is interpreted by us to be of magmatic hydrothermal origin. Although the Leven Star deposit is only a minor, currently subeconomic example of gold mineralisation, the recognition of intrusion-related gold systems in the western Lachlan Orogen has significant implications for exploration models in Victoria (Bierlein \& McKnight 2005).

\section{REGIONAL GEOLOGY}

\section{Western Lachlan Orogen}

The Lachlan Orogen is divided into three subprovinces, which display differences in metamorphic grade, structure and tectonic setting (Gray 1997). The western subprovince of the Lachlan Orogen (Figure 1) is a structurally bound fold and thrust belt that is north- to northwest-trending, east-verging, and low metamorphic grade. The imbricated, chevron-folded turbidite sequence is cut by a series of strike-parallel, west-dipping reverse faults (Gray 1997). The western Lachlan Orogen can be further divided into three distinct structural zones: (i) Stawell, (ii) Bendigo and (iii) Melbourne Zones. These zones are bound by parallel thrust faults that link to a mid-crustal detachment fault to form an east-vergent thrust system (Foster et al. 1998; Foster \& Gray 2000). The deformed turbidites of the western Lachlan Orogen were intruded by large granitic plutons derived from a combination of subduction-generated mantle magmas and lower to middle crustal melts in the Silurian 


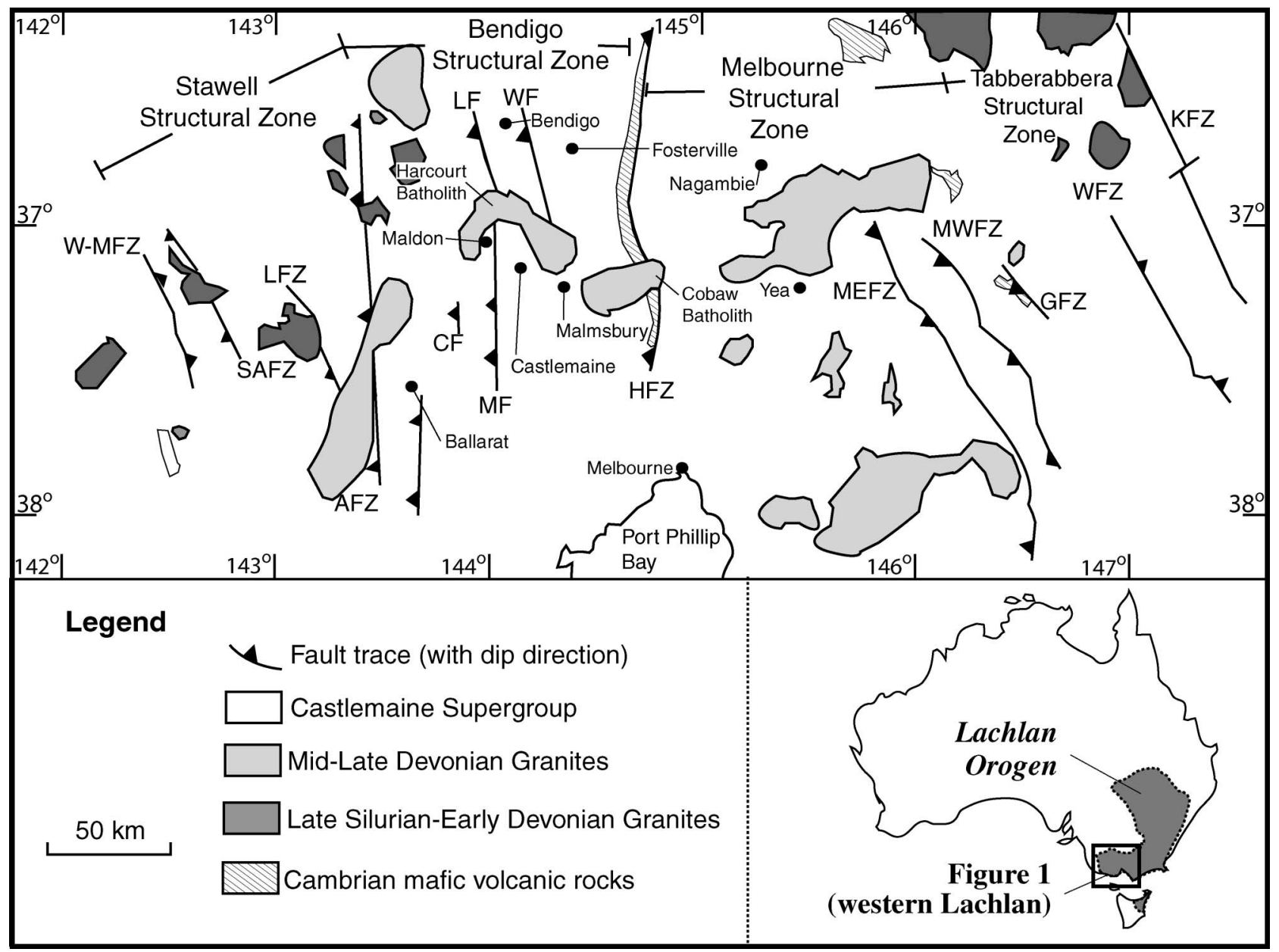

Figure 1 Locality map and structural zones of the western Lachlan Orogen. Bounding faults are AFZ, Avoca Fault Zone; HFZ, Heathcote Fault Zone; MFZ, Moyston Fault Zone; and GFZ, Governor Fault Zone. Also shown are SAFZ, Stawell Ararat Fault Zone; LFZ, Landsborough Fault Zone; CF, Campbelltown Fault; MF, Muckleford Fault; LF, Leichhardt Fault; WF, Whitelaw Fault; MEFZ, Mt Easton Fault Zone; MWFZ, Mt Wellington Fault Zone; KFZ, Kiewa Fault Zone; and gold deposits of the Bendigo and Melbourne zones referred to in the text (modified after Foster et al. 1999).

through to Late Devonian (Chappell et al. 1988; VandenBerg et al. 2000).

The Bendigo Zone consists of a $~ 110 \mathrm{~km}$-wide belt of folded and faulted Cambrian Ordovician quartz-rich turbidites of the Castlemaine Supergroup, deposited on Cambrian oceanic crust. The Castlemaine Supergroup consists of turbiditic sandstone and mudstone sequences and represents the host to the vast majority of orogenic lode gold deposits in this portion of the western Lachlan Orogen (VandenBerg et al. 2000). Regional sub- to midgreenschist metamorphism in the Bendigo Zone is characterised by chlorite and muscovite, and occurred at $455440 \mathrm{Ma}$ (Foster et al. 1999). Sericite dating from major orogenic gold deposits in the Bendigo and Stawell Zones give Ar Ar dates around $440 \mathrm{Ma}$ (Foster et al. 1998; Bierlein et al. 2001a). These ages can be correlated with folding and thrusting indicating that this major mineralisation event took place during, or closely following, peak deformation associated with the Benambran Orogeny (Foster et al. 1998; VandenBerg et al. 2000).

Importantly, available geochronological data indicate that orogenic gold deposits related to metamorphism pre-date the onset of post-tectonic magmatism in the western Lachlan Orogen by up to 80 million years, and that no genetic link exists between the main phase(s) of orogenic gold mineralisation and magmatism in the central Victorian gold province (Foster et al. 1998; Bierlein et al. 2001a, b).

\section{MALMSBURY GOLDFIELD}

The Malmsbury goldfield is located $\sim 5 \mathrm{~km}$ west of the Malmsbury township in the central portion of the Bendigo Zone. This area is located between two Middle Late Devonian batholiths, namely the Cobaw Batholith $10 \mathrm{~km}$ to the east, and the Harcourt Batholith $7 \mathrm{~km}$ to the north (Figure 1).

The Malmsbury goldfield is centred on the Belltopper Hill area which covers an area $\sim 1.0 \mathrm{~km}$ (north south) by $1.5 \mathrm{~km}$ (east west), and consists of Lower Ordovician quartz-rich turbidites of the Castlemaine Supergroup (McKnight \& van Riel 2001) (Figure 2). The turbidite sequence was deformed into northwest- to north-northwest-trending anticlinal and synclinal structures that underwent lower greenschist facies metamorphism. 


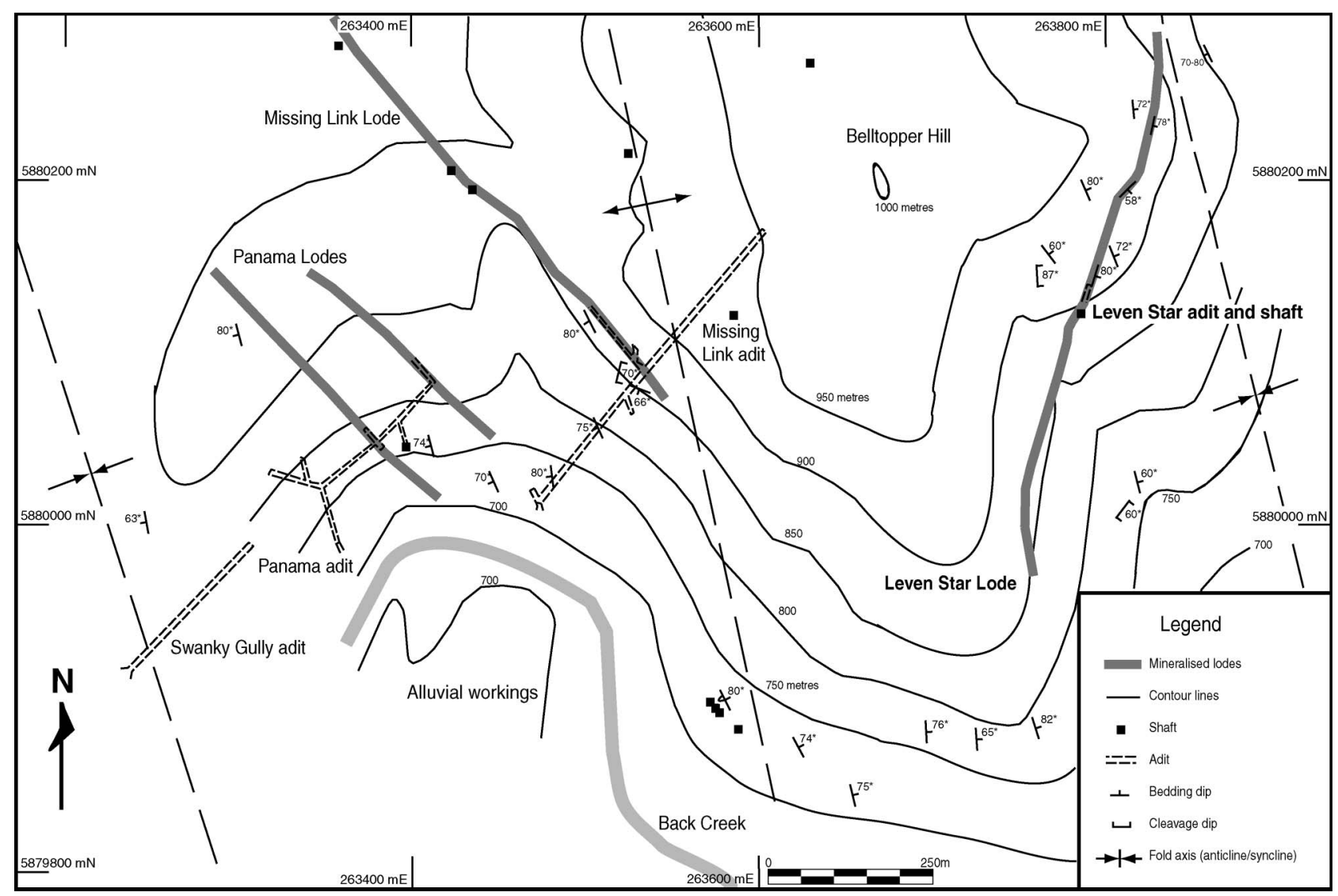

Figure 2 Map of Malmsbury goldfield, showing bedding, cleavage measurements, main fold axes, location of fault hosted quartz lodes, the Leven Star lode, mine shafts and adits (topography and adit locations from Victorian Geological Survey database).

These chevron structures are cut by predominantly southwest-dipping, northwest-trending reverse faults that occur throughout the study area and are largely responsible for creating the dilatational sites responsible for the formation of auriferous quartz lode structures in the Malmsbury goldfield (e.g. Missing Link and Panama lodes: Figure 2). Quartz lode structures in the Malmsbury goldfield are cut by north-northeast- to northeast-trending felsic dykes, several of which are exposed at the surface and old workings (Figure 3). In outcrop, these generally strongly metasomatised and weathered dykes range in length from several metres to $30 \mathrm{~m}$ and reach a thickness of up to $2.5 \mathrm{~m}$. The youngest rocks in the Belltopper Hill area are Tertiary alluvial gravels, which occur in or near present-day streams and valleys (e.g. Back Creek) (Figure 2).

\section{METHODOLOGY}

Over 60 thin-sections and 80 hand-specimens, mainly from drillcore and adit sampling, were taken to define the nature of mineralisation at Leven Star (Figure 2). Thirty-one samples from diamond drillholes were analysed by X-ray diffraction (XRD) at the University of Ballarat using a computer-controlled Siemens D501 diffractometer, operating at $40 \mathrm{kV}$ and $25 \mathrm{~mA}$ using nickel- filtered $\mathrm{CuK}_{\alpha}$ radiation. A quantitative XRD analysis was performed on 19 powdered samples along a traverse in diamond drillhole LSDDH9 $(5880191 \mathrm{mN}, 263862 \mathrm{mE})$ to examine the abundance of alteration and metamorphic minerals and their spatial relationship with the ore zone. Selected polished thin-sections were also chosen for scanning electron microscopy (SEM) and cathodoluminescence studies at the University of Ballarat.

A geochemical whole-rock analysis was performed on eight samples along a traverse on LSDDH1 $(5879892 \mathrm{mN}$, $263817 \mathrm{mE}$ ) and one sample from the Missing Link lode to examine changes in the bulk rock chemistry in the alteration and ore zones. Assays were performed by Amdel, Adelaide (using a total acid digest method, HF $\mathrm{HNO}_{3} \quad \mathrm{HClO}_{4} \mathrm{HCl}$, with an ICP-OES finish for major elements and ICP-MS for selected trace elements) and Becquerel Laboratories [using instrumental neutron activation analysis (INNA) for gold and 31 elements]. Whole-rock data are summarised in Table 1.

Selected double-polished thick-sections of samples taken from vein structures in the Leven Star deposit were analysed for quartz-hosted fluid inclusions using a FLUID INC. heating/freezing stage equipped with a binocular Ortholux microscope (II POLO-MK) with a magnification up to $\times 320$. A thick-section of quartz from the Missing Link lode was also analysed to provide a comparison with fluid compositions in the Leven Star 

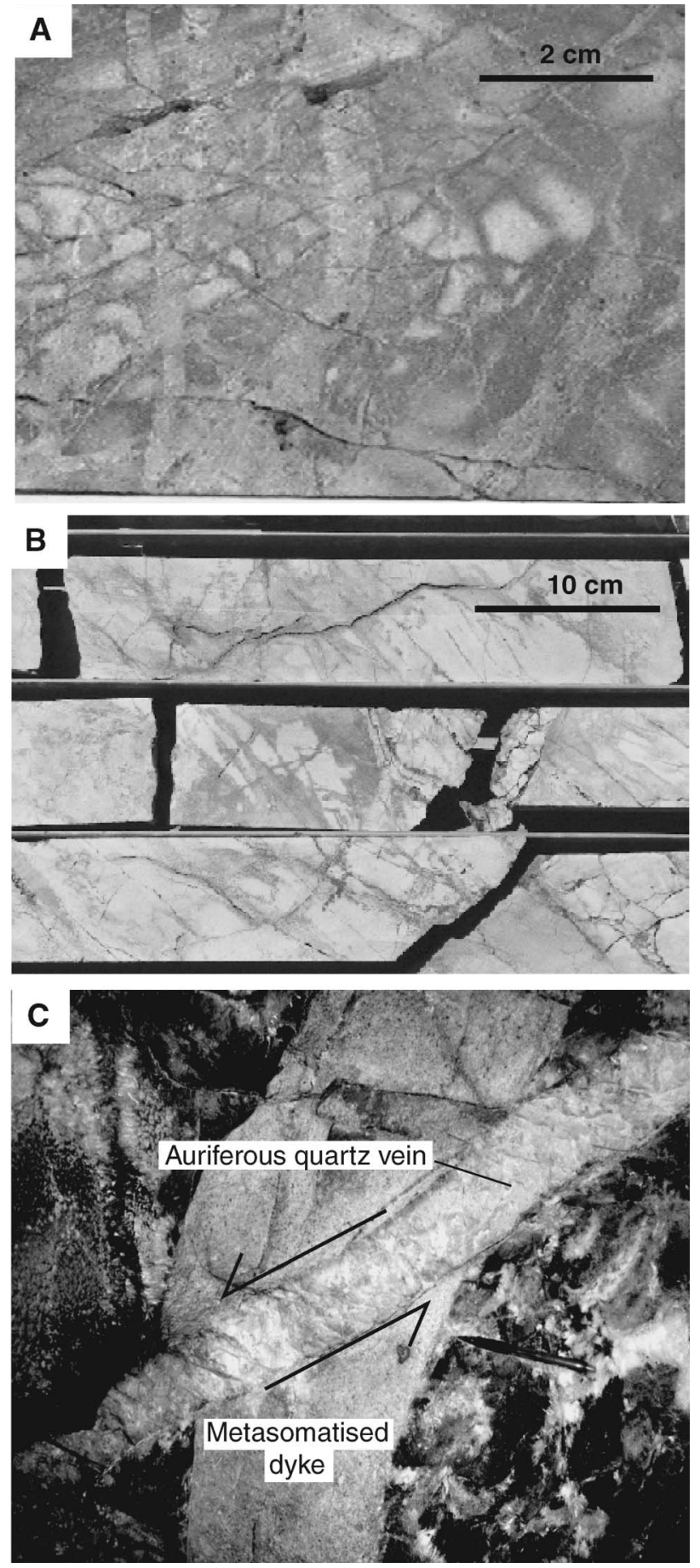

Figure 3 (a) Example of quartz sulfide stockwork breccia and veinlets in psammopelite at Leven Star $(5880278 \mathrm{mN}$, $263784 \mathrm{mE}$ ). (b) Siliceous stockwork breccia in hydrother mally altered and bleached psammopelite (Drillhole LSDDH1, 68.1 70.1m: 5879892mN, 263817mE). (c) Exposure of an extensively metasomatised felsic dyke in the Missing Link adit $(5880209 \mathrm{mN}, 263786 \mathrm{mE})$ (see also Figure 2) showing offset by quartz ( pyrite stibnite) vein related to the mineralisation at Leven Star (modified from Bierlein \& McKnight 2005 figures 3A, B).

deposit. Precise salinity, molar volume and density isochors for the estimated compositions were calculated using the software FLUIDS (Bakker 2003).

\section{LEVEN STAR DEPOSIT}

\section{Geology}

Unlike the surrounding gold-bearing structures in the Malmsbury goldfield, the ore-hosting structure in the Leven Star deposit has a northeast orientation that is almost orthogonal to the dominantly northwest-oriented Panama and Missing Link lodes (Figure 2). The Leven Star deposit comprises a roughly linear fault breccia in a shear zone that can be traced for $\sim 800 \mathrm{~m}$. Extrapolation of diamond drillcore and field observations indicate that this shear zone is subvertical, with pods of fault breccia parallel to the main zone of shearing, and diverging breccia zones that extend out from the main shear into the surrounding wall rock (this study; A. Radojkovic pers. comm. 2002).

The host rocks consist of a deep-water turbiditic sequence of quartz-rich sandstone and black shale, typical of the Castlemaine Supergroup. These rocks have been metamorphosed to lower greenschist facies during a regional thermal event and contain quartz illite chlorite assemblages. Rare calc-silicate nodules or concretions are present throughout the Malmsbury goldfield and comprise fine-grained quartz, carbonate, chlorite and muscovite. The nodules typically range in size from $1 \mathrm{~cm}$ to tens of centimetres. Although uncommon in the Malmsbury goldfield, similar nodules have also been identified in other areas in the western Lachlan Orogen (Morand 1994; Ebsworth et al. 1998). Where the nodules occur within the contact aureoles of granites, they contain a 'skarn-like' assemblage of quartz, plagioclase, garnet, tremolite and carbonate.

In contrast to laminated massive vein structures that are typical of orogenic style deposits throughout the western Lachlan Orogen and elsewhere in the Malmsbury goldfield, the Leven Star deposit consists of quartz-filled breccia with extensive stockworked veinlets (Figure 3a). Importantly, mineralisation is not limited to these veins but is disseminated throughout the surrounding wall rock, in some cases distal from any discernible veining. This occurrence, as well as the bleached appearance of the wall rocks (Figure 3b), implies an extensive and pervasive penetration of the host rock by the mineralising fluid.

The ${ }^{40} \mathrm{Ar} /{ }^{39} \mathrm{Ar}$ analysis of a $\sim 1.2 \mathrm{~mm}$-long hydrothermal muscovite separated from a $\sim 3 \mathrm{~cm}$-wide gold-bearing quartz vein in the Leven Star deposit constrains the age of mineralisation to $368 \pm 2 \mathrm{Ma}$, which is synchronous with the emplacement ages of the nearby Harcourt and Cobaw Batholiths (Bierlein et al. 2001b; Bierlein \& McKnight 2005). This timing relationship is also supported by petrographic evidence and confirmed by field relationships that show that granitic dykes are cut by auriferous vein structures (Figure 3c).

\section{Metamorphism and alteration}

Four main mineralogical associations are preserved in the Leven Star deposit. These have been placed in a relative chronological order (Figure 4): 
Table 1 Whole rock and trace geochemical data.

\begin{tabular}{|c|c|c|c|c|c|c|c|c|c|c|c|c|}
\hline \multicolumn{4}{|c|}{ Analysis details } & \multicolumn{8}{|c|}{ LSDDH1 } & \multirow{2}{*}{$\begin{array}{l}\text { Missing link lode } \\
\text { MLT2 } 9\end{array}$} \\
\hline Units & Scheme & Detection & Analyte & $69.9 \mathrm{~m}$ & $71.6 \mathrm{~m}$ & $75.0 \mathrm{~m}$ & $83.0 \mathrm{~m}$ & $86.0 \mathrm{~m}$ & $88.3 \mathrm{~m}$ & $92.0 \mathrm{~m}$ & $94.8 \mathrm{~m}$ & \\
\hline wt \% & ICP & 0.01 & $\mathrm{SiO}_{2}$ & 80.0 & 85.6 & 83.6 & 70.8 & 74.5 & 80.2 & 73.9 & 79.7 & 73.9 \\
\hline wt $\%$ & ICP & 0.01 & $\mathrm{Al}_{2} \mathrm{O}_{3}$ & 12.6 & 6.9 & 9.1 & 11.7 & 11.3 & 10.2 & 15.5 & 12.5 & 11.4 \\
\hline wt $\%$ & ICP & 0.01 & $\mathrm{Fe}_{2} \mathrm{O}_{3}$ & 0.71 & 2.18 & 1.12 & 9.6 & 5.13 & 1.86 & 1.34 & 0.98 & 3.54 \\
\hline wt \% & ICP & 0.01 & $\mathrm{MgO}$ & 0.22 & 0.29 & 0.16 & 0.34 & 0.40 & 0.63 & 0.36 & 0.28 & 1.48 \\
\hline wt \% & ICP & 0.01 & $\mathrm{CaO}$ & 0.04 & 0.07 & 0.09 & 0.11 & 0.11 & 0.09 & 0.07 & 0.04 & 0.26 \\
\hline wt \% & ICP & 0.01 & $\mathrm{Na}_{2} \mathrm{O}$ & 0.15 & 0.08 & 0.11 & 0.15 & 0.18 & 0.05 & 0.20 & 0.09 & 0.40 \\
\hline wt \% & ICP & 0.01 & $\mathrm{~K}_{2} \mathrm{O}$ & 2.10 & 1.66 & 1.51 & 2.64 & 2.55 & 2.08 & 3.14 & 1.90 & 2.26 \\
\hline wt \% & ICP & 0.01 & $\mathrm{P}_{2} \mathrm{O}_{5}$ & 0.05 & 0.05 & 0.07 & 0.08 & 0.20 & 0.08 & 0.06 & 0.06 & 0.13 \\
\hline ppm & ICP & 0.05 & $\mathrm{Ag}$ & $<0.05$ & $<0.05$ & $<0.05$ & $<0.05$ & $<0.05$ & $<0.05$ & $<0.05$ & $<0.05$ & $<0.05$ \\
\hline ppm & INAA & 0.1 & As & 50 & 446 & 51 & 456 & 870 & 277 & 134 & 90 & 4 \\
\hline $\mathrm{ppb}$ & INAA & 5 & $\mathrm{Au}$ & 39 & 117 & 13 & 105 & 9610 & 411 & 32 & 260 & 5 \\
\hline ppm & ICP & 3 & $\mathrm{Bi}$ & $<3$ & $<3$ & $<3$ & $<3$ & $<3$ & $<3$ & $<3$ & $<3$ & $<3$ \\
\hline ppm & INAA & 1 & Co & $<1$ & 1 & $<1$ & 1 & 4 & $<1$ & $<1$ & $<1$ & 15 \\
\hline ppm & ICP & 1 & $\mathrm{Cu}$ & 6 & 39 & 9 & 50 & 44 & 10 & 8 & 9 & 110 \\
\hline ppm & INAA & 2 & Мo & 0 & 4 & 3 & 4 & 6 & 2 & 2 & 4 & 5 \\
\hline ppm & ICP & 1 & $\mathrm{Ni}$ & 2 & 3 & 2 & 3 & 10 & 3 & 2 & 2 & 32 \\
\hline ppm & ICP & 3 & $\mathrm{~Pb}$ & 6 & 10 & 10 & 22 & 18 & 8 & 20 & 30 & 14 \\
\hline ppm & INAA & 5 & $\mathrm{Te}$ & $<5$ & $<5$ & $<5$ & $<5$ & $<5$ & $<5$ & $<5$ & $<5$ & $<5$ \\
\hline ppm & INAA & 2 & W & 30 & 53 & 16 & 17 & 30 & 44 & 24 & 42 & 15 \\
\hline ppm & INAA & 0.2 & $\mathrm{Zn}$ & 5 & 53 & 135 & 52 & 278 & 385 & 66 & 50 & 148 \\
\hline
\end{tabular}

Data generated using a combination of a total acid digest method with an ICP OES finish (ICP, Amdel Laboratories, Adelaide) and instrumental neutron activation analysis (INAA, Becquerel Laboratories, Sydney).

LSDDH1, 5879892mN, 263817mE; MLT2 9, 5880142mN, 263538mE.

Figure 4 Paragenetic sequence of minerals in the alteration halo of the Leven Star deposit. Bold lines indicate a mineral occurring in each geological association [regio nal metamorphism, contact meta morphism, early hydrothermal alteration (metasomatism) and late hydrothermal alteration]; dotted lines indicate an uncertain association due to the relative rarity of these mineral phases.




(1) Regional metamorphism A muscovite chlorite quartz assemblage most evident in least-altered samples and interpreted to be a result of the Benambran Orogeny. This assemblage becomes less evident towards the ore zone (Figure 5) as chlorite is increasingly altered to biotite, sericite, and carbonate.

(2) Contact metamorphism On a deposit-scale, assemblages in the host rocks of Leven Star are characterised by a dominant biotite cordierite assemblage that is indicative of contact metamorphism (Deer et al. 1992). These overprint the regional metamorphic assemblage and imply a significant thermal event occurred, at least in the area of the Malmsbury goldfield, after regional peak metamorphism. This mineral assemblage and high temperature ( $\sim 450550^{\circ} \mathrm{C}$ : Deer et al. 1992$)$ are characteristic of thermal contact aureoles surrounding intrusive bodies (Chappell et al. 1988). This assemblage is found throughout the wall rock of Leven Star and extends beyond the hydrothermal alteration halo (Figure 5). Biotite abundance decreases toward the ore zone in the Leven Star deposit due to increasing sericitisation of this mineral (Figure 6); cordierite is almost completely retrogressed to sericite.
(3) Metasomatism (early hydrothermal alteration) The effects of a metasomatic event can be observed in minor alteration assemblages displaying skarn-like minerals. This assemblage is characterised by coarse blades (up to $3 \mathrm{~mm}$ in length) of calcite and dolomite, with later stage fluorite, cassiterite, scheelite and wolframite (Figure 7). The Sn W F minerals are most abundant in the carbonate assemblages but are also found throughout the host rocks of Leven Star. The skarn-like textures and mineralogy of calcite and dolomite evident in the Leven Star deposit, while perhaps indicative of a magmatic association, are too rare to be indicative of an igneousassociated skarn-type mineralisation control at Leven Star. Instead, we consider this assemblage to be a remnant of diagenetic carbonate nodules that have undergone metasomatism during the early stages of mineralisation.

(4) Late hydrothermal alteration The ore-forming fluids in the Leven Star deposit are associated with a sulfide carbonate sericite silica alteration assemblage commonly found in orogenic gold deposits throughout the Bendigo Zone (Bierlein et al. 2000). However, on the basis of ${ }^{40} \mathrm{Ar} /{ }^{39} \mathrm{Ar}$ data, field evidence and petrography, we infer

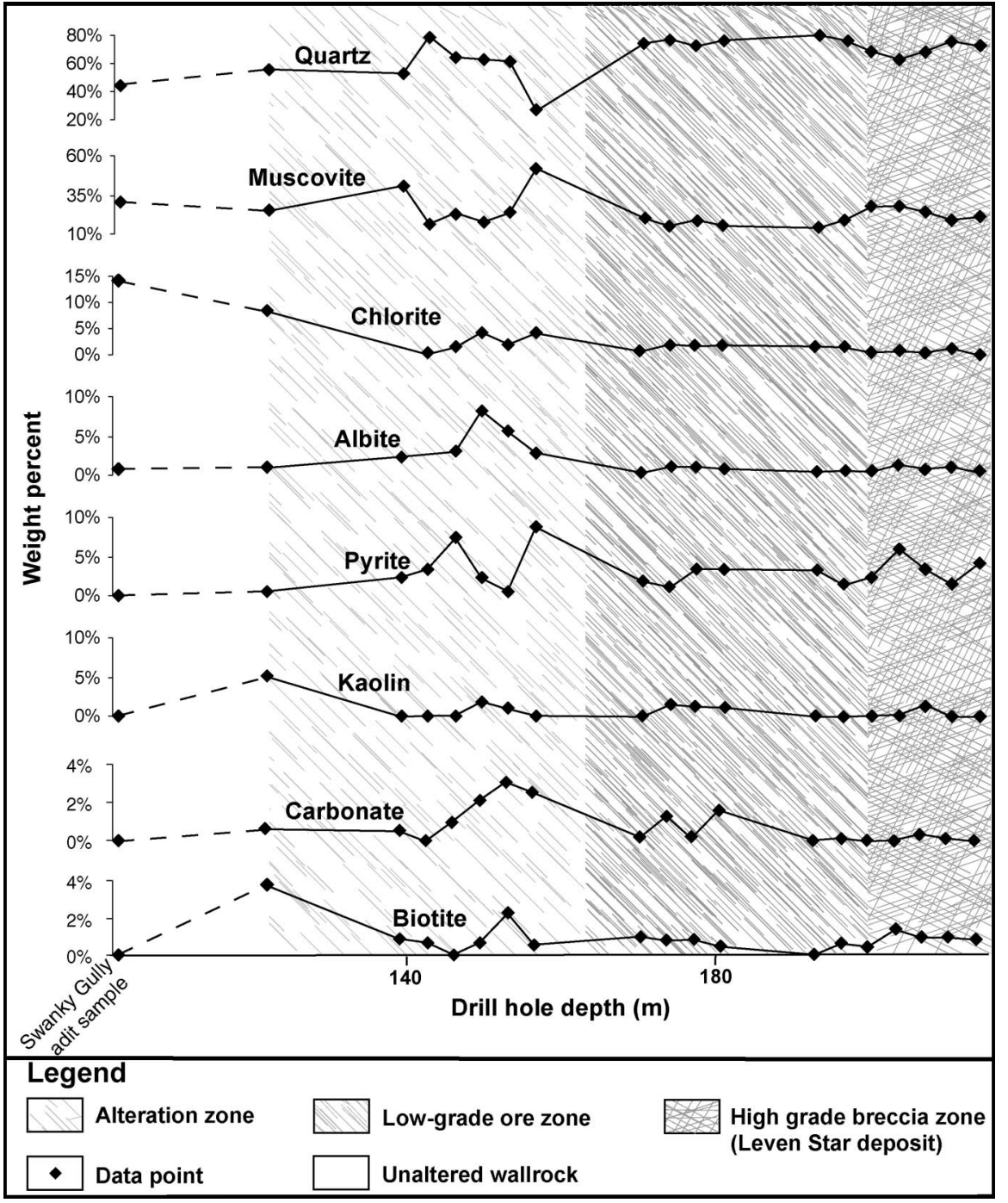

Figure 5 Mineral abundance plots from quantitative XRD analysis along a traverse in drillhole LSDDH9 (5880191mN, 263862mE). Plot divided into the Leven Star ore zone with disseminated mine ralisation (gold bearing breccia zone), low grade disseminated mineralisation (low grade zone), altered, less silicified halo (altera tion zone), and the Swanky Gully adit sample, which is relatively unweathered and considered the least altered sample in the Malmsbury goldfield study area. 
this hydrothermal event to be coeval with, or post-dating, the emplacement of nearby Middle Late Devonian granites. In marked contrast to several orogenic gold deposits elsewhere in the central Victorian gold province that have been overprinted by contact metamorphism (e.g. at Linton, Stawell and Maldon: Mapani \& Wilson 1998; Bierlein et al. 2000, 2001a, b), the hydrothermal alteration assemblage clearly overprints the earlier contact metamorphic assemblage (Figures 4,6). The effects of alteration are also graphically displayed in mineral abundance plots (Figure 5), where the abundance of sericite and carbonate alteration exhibits an antithetic relationship to biotite,

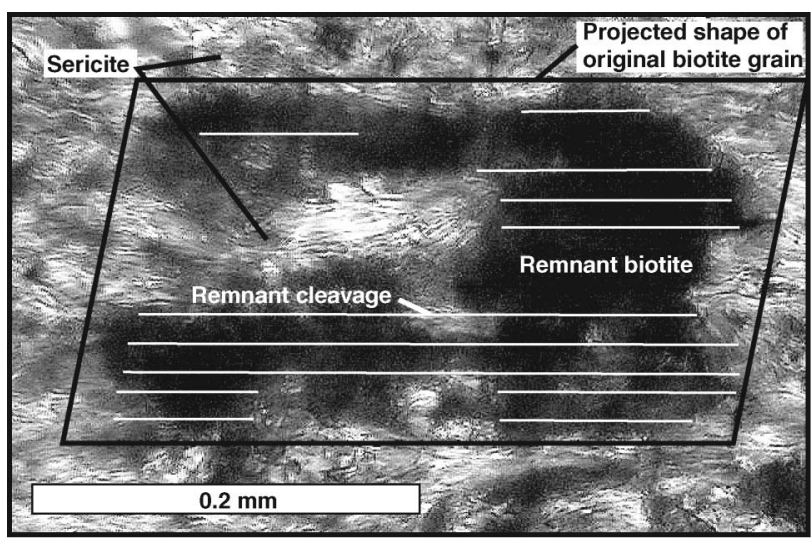

Figure 6 Photomicrograph (crossed polars, transmitted light) of biotite in a hydrothermally altered pelite (LSDDH9, $144.4 \mathrm{~m}$ : 5880191mN, 263862mE: sample RW04/AA4 23, Monash University). This field of view shows a biotite grain that has been rimmed and partially altered to hydrothermal sericite, demonstrating the temporal relationship between the (early) contact metamorphism and (late) hydrothermal alteration observed at Leven Star. Also shown is the original shape of the euhedral biotite crystal, with rare remnant cleavage preserved (superimposed in black).

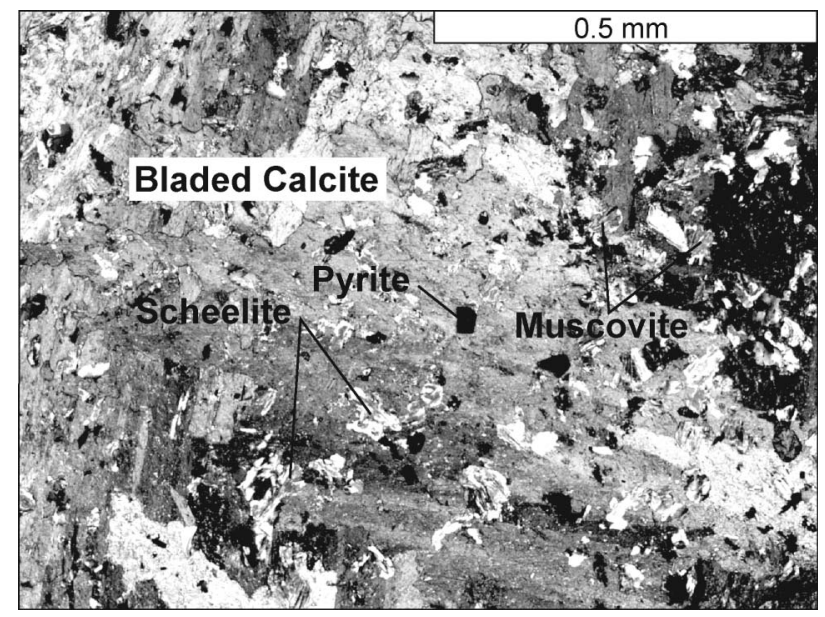

Figure 7 Photomicrograph of scheelite mineralisation in a skarn like assemblage of bladed calcite within a calc silicate nodule (LSDDH9, $147.7 \mathrm{~m}$ : 5880191mN, 263862mE: sample RW04/AA4 24, Monash University). Muscovite and pyrite overprint the skarn like assemblage (Crossed polars, trans mitted light). supporting petrological observations showing that the thermal metamorphic assemblage is overprinted by the hydrothermal alteration assemblage.

\section{Alteration geochemistry}

A comparison of hydrothermally altered whole-rock samples taken from the ore zone in the Leven Star deposit with background samples well away from the deposit indicates a distinct $\mathrm{Au} \mathrm{As} \mathrm{Sb}$ metal enrichment in the ore zone of Leven Star (Figure 8). The geochemical data confirm a strong positive association between these metals as evidenced petrographically by the abundant presence of arsenopyrite and stibnite in the gold-bearing breccia zone. In addition to the dominant $\mathrm{Au} \mathrm{As} \mathrm{Sb}$ metal association, Co, Ni, Mo, $\mathrm{Cu}, \mathrm{Zn}$ and $\mathrm{Pb}$ are also elevated in the mineralised zone (Figure 9a; Table 1). However, only $\mathrm{Zn}$ is present in sufficient quantities (up to $385 \mathrm{ppm}$ ) to indicate an enrichment in association with the mineralisation at Leven Star (as evidenced also by rare occurrences of sphalerite in thin-section).

The geochemical alteration halo surrounding the Leven Star deposit, while extending for at least $20 \mathrm{~m}$ from the ore zone, shows only subtle changes in the bulk geochemistry. Major element concentrations are largely unaffected by hydrothermal alteration, but instead are controlled predominantly by lithology. As expected, the more coarse-grained metasandstones yield elevated $\mathrm{SiO}_{2}$ relative to more pelitic samples, with higher $\mathrm{Al}_{2} \mathrm{O}_{3}, \mathrm{Fe}_{2} \mathrm{O}_{3}, \mathrm{MgO}$ and $\mathrm{K}_{2} \mathrm{O}$ in the latter reflecting higher abundances of carbonates, finegrained white mica (muscovite, sericite) and biotite (Figure 9b).

Notably, $\mathrm{Na}_{2} \mathrm{O}$ concentrations in the alteration zone (0.1 $0.6 \mathrm{wt} \%)$ are well below average values for unaltered sandstones and shales of the Castlemaine Supergroup (Bierlein et al. 2000). This depletion of $\mathrm{Na}$ during hydrothermal alteration is reflected petrologically by the breakdown and removal of albite in the alteration zone (Figure 5). $\mathrm{CaO}$ and $\mathrm{P}_{2} \mathrm{O}_{5}$ abundances in Figure $9 \mathrm{~b}$ demonstrate a gradual increase in these



Figure $8 \mathrm{Log} / \mathrm{Log}$ element abundance plot of a mineralised sample (LSDDH1, $86.0 \mathrm{~m}: 5879892 \mathrm{mN}, 263817 \mathrm{mE}$ ), which shows a distinct enrichment in $\mathrm{Au}, \mathrm{As}$ and $\mathrm{Sb}( \pm \mathrm{Zn}$ and $\mathrm{W})$ $v s$ the least altered sample (MLT 9). 
elements towards the mineralised breccia zone, and reflect carbonatisation and the precipitation of hydrothermal phases such as fluorite, scheelite, monazite and apatite.

\section{Sulfide/oxide mineral assemblage}

The diverse mineralogy in the Leven Star deposit is dominated by pyrite, arsenopyrite and stibnite, which are abundant in most mineralised samples, with minor amounts of pyrrhotite, marcasite and sphalerite also present. In addition to these major sulfide phases, observations using petrography and SEM analyses have also identified a number of minor mineral phases (Table 2).

\section{Evidence for multiple phases of mineralisation}

Petrographic observations and SEM analyses indicate a complex mineralised system for the Leven Star gold deposit, with evidence for multiple, overprinting fluid and vein-forming events due to episodic fracturing of the wall rock. This complex evolution is preserved in



(a)

Figure 9 (a) Selected trace element abundances asso ciated with mineralisation in the Leven Star Lode $v s$ drill hole depth in LSDDH1 $(5879892 \mathrm{mN}, 263817 \mathrm{mE})$. Main shear zone is located at hole depth of $86.0 \mathrm{~m}$. (b) Selected major element abundances as sociated with mineralisation in the Leven Star Lode $v s$ drillhole depth in LSDDH1. 
(b)

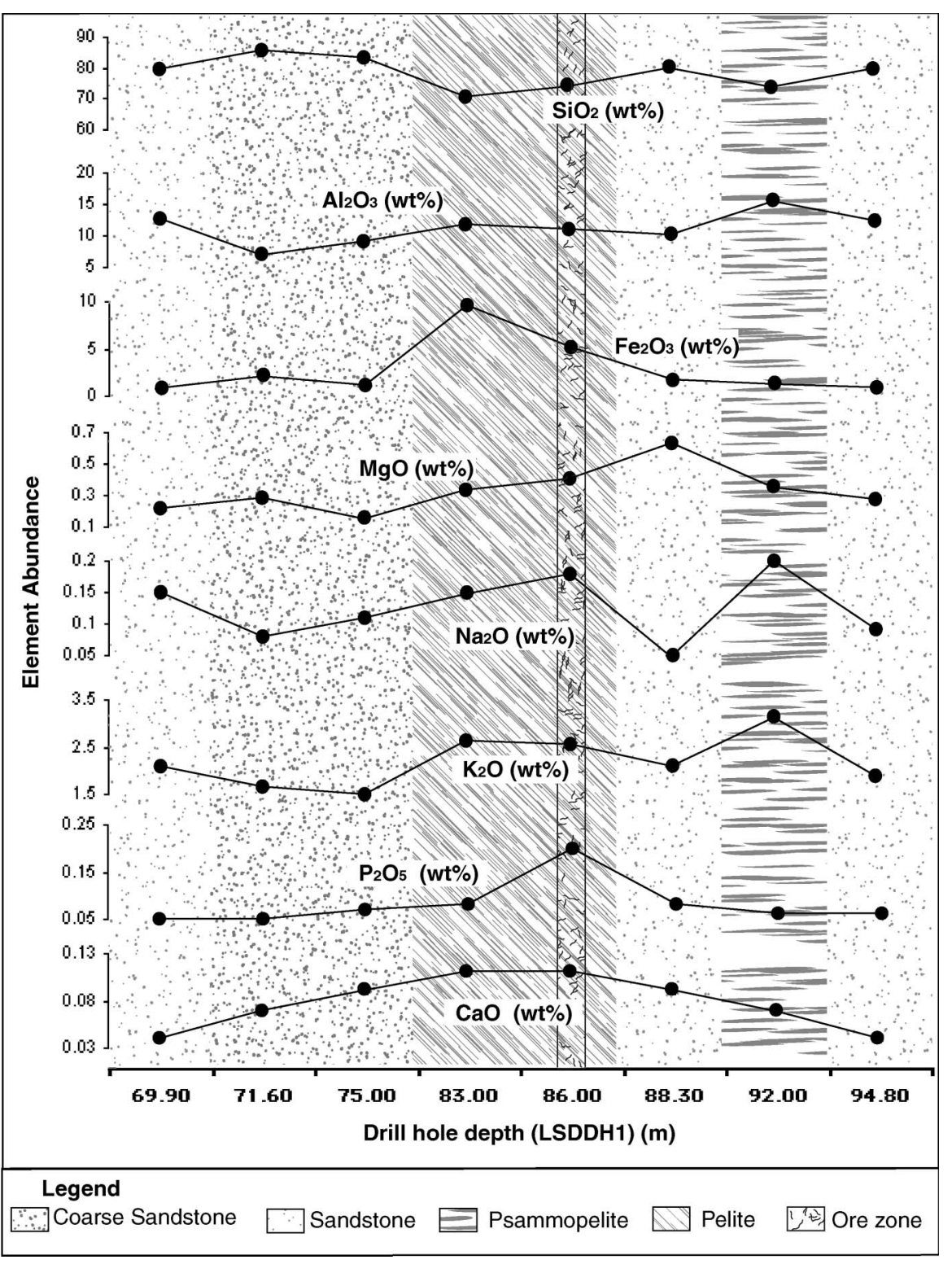

Figure 9 (Continued).

cathodoluminescence images of mineralised quartz veins, where crystal growth patterns (Figure 10a, b) indicate multiple zonation during mineral growth. In addition, quartz in ore-bearing veins displays evidence for multiple mineralising events associated with fracturing and brecciation (Figure 10c f). Textural evidence, such as oscillatory zonation in arsenopyrite (below), also indicates that emplacement of sulfides (and gold) at Leven Star was controlled by multiple fracturing events, which led to the formation of breccia and extensive stockwork veining found in the ore zone.

\section{Occurrence of gold}

In contrast to the coarse-grained nature of free gold typical of most orogenic gold deposits throughout the Bendigo Zone (Bierlein et al. 2001a), detailed petrographical examination and SEM analyses indicate that most of the gold in the Leven Star deposit is refractory in nature and occurs as a solid solution within disseminated arsenopyrite grains (Bierlein \& McKnight 2005). Other major sulfides (stibnite and pyrite) are generally gold-free (i.e. $<100 \mathrm{ppm} \mathrm{Au}$ ). Electron microprobe element mapping of arsenopyrite (Figure 11) reveals a heterogenous distribution of refractory gold and antimony between and within individual arsenopyrite grains. The arsenopyrite grains are typically characterised by distinct chemical zonation patterns, with $\mathrm{Au}$ and $\mathrm{Sb}$ concentrations displaying an antipathetic relationship. The great majority of arsenopyrite grains analysed consist of Au-poor, Sb-rich cores surrounded by Au-rich, Sb-poor rim zones (Figure 11). Overall, all arsenopyrite grains analysed were Asdeficient, with atomic ratios of As/S ranging from 0.63 to 0.98 and atomic As ranging from 25 to $33 \%$. The most As-deficient compositions approach $\mathrm{Fe}_{3} \mathrm{As}_{2} \mathrm{~S}_{4}$ and imply that a significant $\mathrm{FeS}_{2}$ solid-solution phase is present. This relationship of As content correlating with $\mathrm{Au}$ and 
$\mathrm{Sb}$ in solid solution has been reported in a variety of gold deposits (Duller et al. 1997; Genkin et al. 1998; Ashley et al. 1999), where $\mathrm{Au}$ is found to be associated with As-rich zones of arsenopyrite and arsenian pyrite, with Sb commonly occurring in an inverse association with $\mathrm{Au}$ and $\mathrm{As}$ in the mineralised grain.

Table 2 Accessory minerals observed in the Leven Star deposit.

Calcite $\mathrm{CaCO}_{3}$

Fluorite $\mathrm{CaF}_{2}$

Scheelite $\mathrm{CaWO}_{4}$

Wolframite (Fe, Mn) $\mathrm{WO}_{4}$

Cassiterite $\mathrm{SnO}_{2}$

Apatite $\mathrm{Ca}_{5}\left(\mathrm{PO}_{4}\right)_{3}(\mathrm{OH}, \mathrm{F}, \mathrm{Cl})$

Tetrahedrite $(\mathrm{Cu}, \mathrm{Ag})_{10}(\mathrm{Zn}, \mathrm{Fe}, \mathrm{Hg})_{2}(\mathrm{Sb}, \mathrm{As})_{4} \mathrm{~S}_{13}$

Tellurbismuth $\mathrm{Bi}_{2} \mathrm{Te}_{3}$

Stibnite $\mathrm{Sb}_{2} \mathrm{~S}_{3}$

Bismuth sulfosalts (auriferous)

Cobaltian breithauptite (Ni, Co)Sb

Native bismuth $\mathrm{Bi}$

Tetradymite $\mathrm{Bi}_{2} \mathrm{Te}_{2} \mathrm{~S}$

Monazite (Ce, La, Th) $\mathrm{PO}_{4}$
Closer examination of trace-element patterns in sulfides suggests that the mineralisation paragenesis is not a simple core rim, bi-phase precipitation system, but an oscillatory system reflecting multiple periods of mineralisation. Element mapping of numerous grains shows that the highest concentrations of gold occur on the boundary between the rim and the core zones, indicating a relatively abrupt change in mineralising conditions. Notably, the zonation patterns are parallel to grain boundaries and strongly suggest the presence of oscillatory zoning in the rim zone(s).

An example of oscillatory zoning in arsenopyrite grains from the Leven Star deposit can be seen in Figure 12. This grain also shows two distinct phases of mineralisation and resembles a microbreccia. In this example, the appearance of the distinctive oscillatory zoning (a function of As-enrichment) in the backscattered electron image can be interpreted as broken fragments. In trace-element maps (Figure 12b, c), the microbreccia appears as Sb-rich, Au-poor fragments surrounded by an enclosing As- and Au-rich Sb-poor matrix filling the space between the fragments. This relationship between the textural and chemical changes


Figure 10 (a) Cathodoluminescence (CDL) and (b) backscattered electron (BSE) images of quartz crystals in vein related to mineralisation at Leven Star (sample RW04/AA3 MLV11, Monash University); the images are parallel to the orientation of the vein structure, with the host rock boundary situated near the lower margin of the images. These images display growth patterns in the quartz visible only with cathodoluminescence. Also observed in this view is a later generation of interstitial lower luminescent quartz. The sulfide assemblage that surrounds each crystal in (b) appears to be associated with low luminescent quartz. Note that the overall brightness of both quartz generations was high, and the contrast of the CDL image was increased to better view variations in intensity. (c) BSE and (d) CDL images of a quartz vein hosting disseminated stibnite mineralisation (LSDDH14, $99.3 \mathrm{~m}: 5880298 \mathrm{mN}$, 263875mE: sample RW04/AA4 40, Monash University). The BSE image (c) shows massive quartz with disseminated sulfides (mainly stibnite). The CDL image (d) displays at least two major generations of quartz, where the first generation occurs as dark angular fragments in a matrix of smaller quartz crystals with a distinctly higher intensity cathodoluminescence. This second generation also appears to be cut by a third quartz vein generation (illustrated by black lines) with a slightly lower cathodoluminescence. It is the two latter generations that contain sulfides (c). (e) BSE and (f) CDL images of disseminated sulfides in a brecciated quartz vein from the Leven Star ore zone (LSDDH14, $99.3 \mathrm{~m}$ : 5880298mN, 263875mE: sample RW04/AA4 40, Monash University). The BSE image shows the sulfides among the highly luminescent quartz, with a fragment of earlier, darker quartz at the top of the image. 

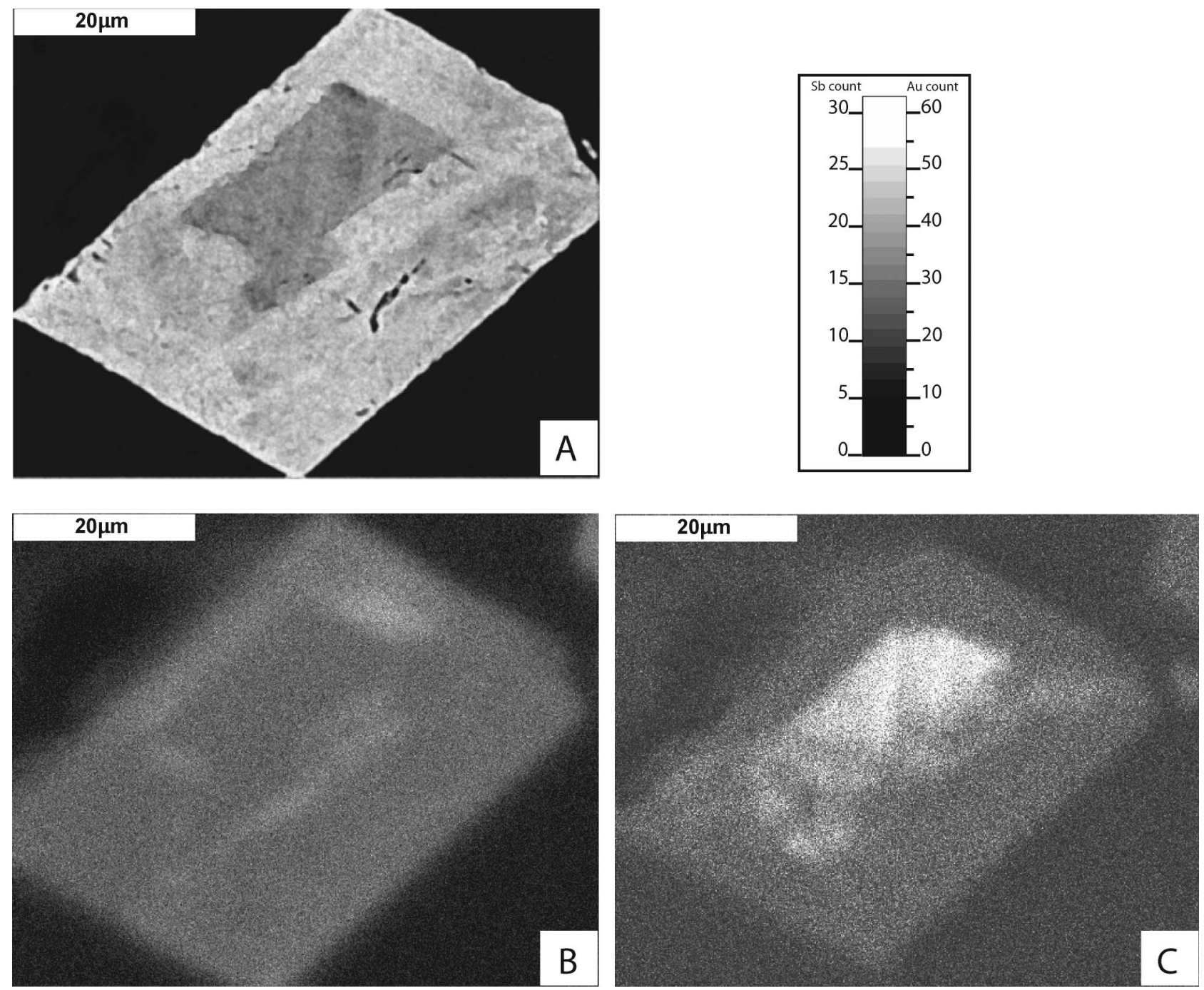

Figure 11 (a) Backscattered electron (BSE) image and (b, c) trace element maps of a pseudo orthorhombic arsenopyrite grain from the Leven Star deposit (LSDDH9, $99.3 \mathrm{~m}: 5880191 \mathrm{mN}, 263862 \mathrm{mE}$ ). The BSE image (a) clearly shows the dark Sb rich core surrounded by the lighter Au rich rim. Trace element X ray maps (b, c) show the antipathetic distributions of gold and antimony using the displayed grey scale.

illustrated in Figure 12 implies that the brecciation of originally oscillatory-zoned arsenopyrite is followed by precipitation of an Au-rich, Sb-poor phase of arsenopyrite that cements the brecciated fragments into a single grain. The occurrence of this process also explains the numerous dark, barren inclusions noted in backscattered electron images and trace-element maps within these types of grains, where angular microfragments such as quartz have been introduced into the arsenopyrite microbreccia (Figure 12).

\section{Fluid inclusions}

Three different types of fluid compositions have been recognised and commonly are coeval in veins related to mineralisation at the Leven Star deposit (Figure 13a c): $\mathrm{H}_{2} \mathrm{O}$-rich (Type 1), $\mathrm{CO}_{2}$-rich (Type 2) and $\mathrm{H}_{2} \mathrm{O} \quad \mathrm{CO}_{2}$-rich (Type 3). These inclusion types are low moderate salinity (3 $12 \mathrm{wt} \% \mathrm{NaCl}$ equiv.; mode at $7 \mathrm{wt} \% \mathrm{NaCl}$ equiv.) two-phase aqueous fluids. A summary of the microthermometric data is given in Table 3.

\section{TYPE 1 INCLUSIONS}

Type 1 inclusions have a relatively transparent appearance, comprise a liquid-rich, bi-phase liquid vapour $(\mathrm{L}+\mathrm{V})$ system at room temperature (Figure 13a), and are the most abundant fluid-inclusion type found in the quartz vein generation.

Homogenisation temperatures for Type 1 inclusions range from 150 to $350^{\circ} \mathrm{C}$ with a strong mode at $188 \pm$ $12^{\circ} \mathrm{C}$ and a broad tail towards higher temperatures (Figure 14). This atypically wide distribution of homogenisation temperatures is considered strong evidence for the occurrence of boiling (Roedder 1984; Wilkinson 2001). This homogenisation mode can be explained via individual inclusions having trapped a mixture of two phases (e.g. $\mathrm{H}_{2} \mathrm{O}$ liquid and vapour $\pm \mathrm{CO}_{2}$ ) rather than a single homogenous phase. As the immiscibility solvus closes at higher temperatures, this trapped mixture will result in inclusions with a higher $T_{\mathrm{h}}$ than would be obtained with inclusions that trapped only liquid or gas (Roedder 1984). Thus, it is the mode at $188 \pm 12^{\circ} \mathrm{C}$ defined 

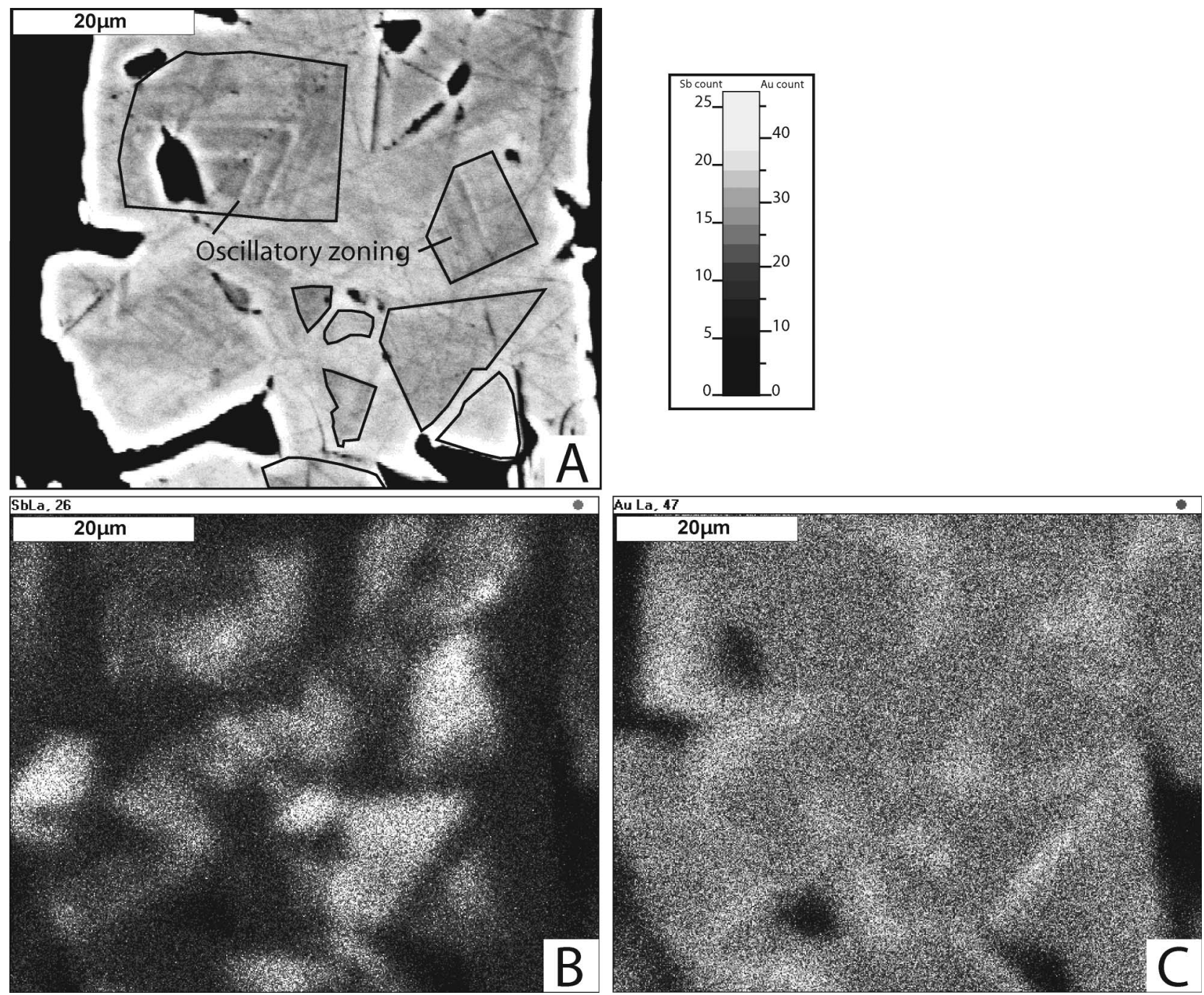

Figure 12 (a) Backscattered electron (BSE) image and trace element maps (b, c) of an arsenopyrite grain from the Leven Star deposit (LSDDH9, $99.3 \mathrm{~m}$ : 5880191mN, 263862mE). The BSE image (a) of the arsenopyrite grain clearly shows oscillatory zoning in the breccia pieces. Trace element X ray maps (b, c) show the distribution of antimony (b) and gold (c). The breccia pieces themselves appear Sb rich and Au poor, while the enclosing arsenopyrite appears Sb poor and Au rich.

by liquid- and vapour-rich Type 1 inclusions that is considered to most accurately represent the temperature of trapping $\left(T_{\mathrm{t}}\right)$. The extended tail to $\sim 350^{\circ} \mathrm{C}$ in Figure 14 is interpreted to represent inclusions that have trapped both liquid and vapour, implying a period of boiling in the hydrothermal system.

\section{TYPE 2 INCLUSIONS}

Carbonic Type 2 fluid inclusions are characterised by a highly refractive bubble, which gives the phase boundary a thick, dark appearance (Figure 13b), common in $\mathrm{CO}_{2}$-rich fluid inclusions (Roedder 1984). Carbonic inclusions range in size from 40 to $290 \mu \mathrm{m}$ and usually appear as a liquid-rich monophase (L) system until cooled to $\sim+11^{\circ} \mathrm{C}\left(\mathrm{T}_{\mathrm{h}}, \mathrm{CO}_{2}\right)$, at which the $\mathrm{CO}_{2}$ vapour phase appears. These inclusions consist of $\mathrm{CO}_{2}$ with little water, but probably contain other gases given the slightly raised $T_{\mathrm{m}} \mathrm{CO}_{2}$ values that range from $57^{\circ} \mathrm{C}$ to $61^{\circ} \mathrm{C}\left(58.8^{\circ} \mathrm{C}\right)$ against the melting temperature of pure $\mathrm{CO}_{2}\left(56.6^{\circ} \mathrm{C}\right)$. In two instances, this unknown gas was isolated in a liquid phase within the solid $\mathrm{CO}_{2}$ during supercooling of the sample (below $100^{\circ} \mathrm{C}$ ). Given the low temperature of freezing, this contaminant gas probably consists of $\mathrm{CH}_{4}$ and $\mathrm{N}_{2}$, with $\mathrm{CH}_{4}$ considered to be the dominant phase due to observation of a vapour liquid phase change at $95^{\circ} \mathrm{C}$. Using the 'Loner' fluid-inclusion computer program series of Bakker (2003), the proportion of additional volatile gases was estimated at $\sim 3 \mathrm{~mol} \% \mathrm{CH}_{4}$ equiv. in the fluid, with $\sim 5 \mathrm{~mol}_{\%} \mathrm{CH}_{4}$ equiv. (average value) occurring in the vapour phase (calculated from Donnelly \& Katz 1954; Burruss 1981).

Type $2 \mathrm{CO}_{2}$ inclusions, due to the $\mathrm{CO}_{2}$ critical point $\left(31^{\circ} \mathrm{C}\right)$ being at a much lower temperature than $\mathrm{H}_{2} \mathrm{O}$ $\left(374^{\circ} \mathrm{C}\right)$, homogenise between 11.5 and $14.5^{\circ} \mathrm{C}$, with a mean of $\sim 12^{\circ} \mathrm{C}$.

\section{TYPE 3 INCLUSIONS}

These inclusions occur as a two-phase system with $\mathrm{H}_{2} \mathrm{O}$ liquid and $\mathrm{CO}_{2}$ vapour bubble at room temperature and 
are characterised by the nucleation of a $\mathrm{CO}_{2}$ liquid on cooling to $\sim 14^{\circ} \mathrm{C}$ (Figure 13c). Type 3 inclusions generally range in size from 30 to $110 \mu \mathrm{m}$, and display similar $\mathrm{H}_{2} \mathrm{O} / \mathrm{CO}_{2}$ ratios at room temperature within
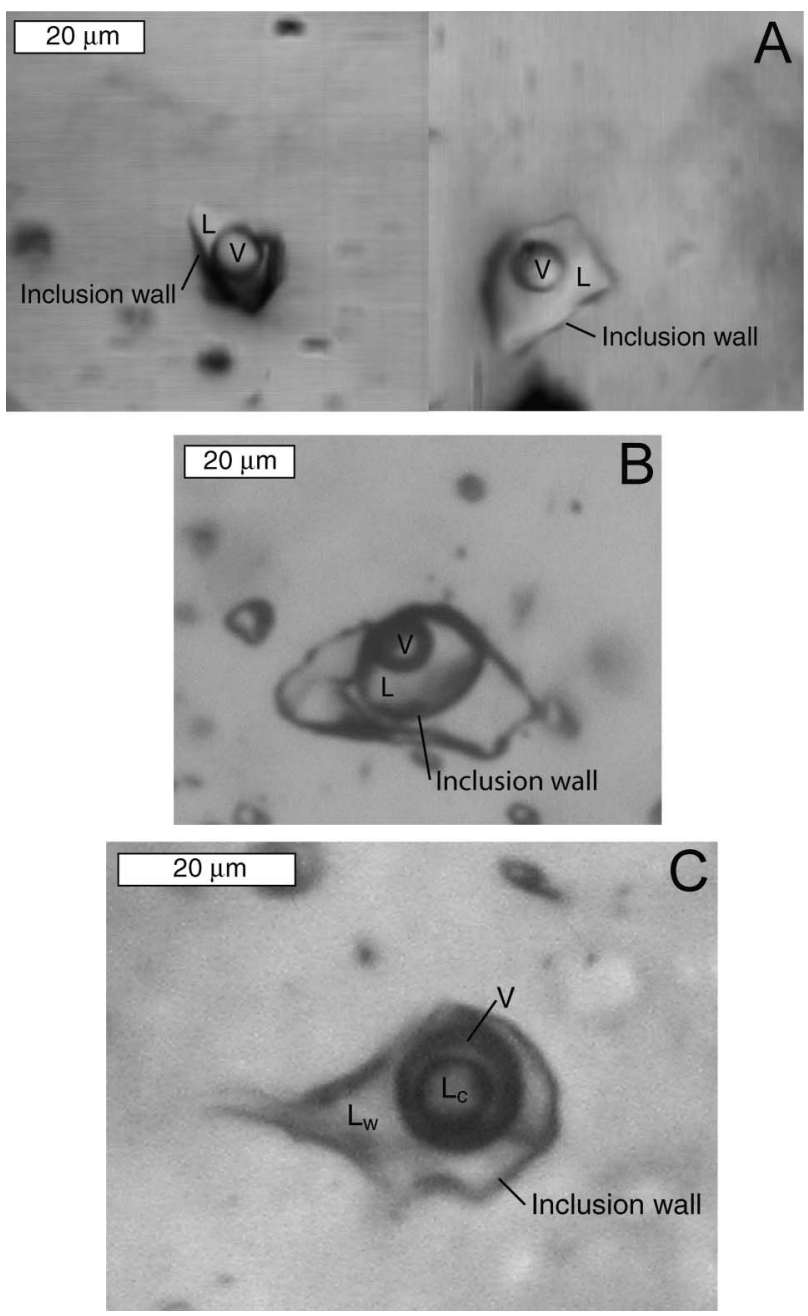

Figure 13 Photomicrographs of (a) Type 1, (b) Type 2, and (c) Type 3 fluid inclusions (plane polarised transmitted light). (a) At room temperature: $\mathrm{V}, \mathrm{H}_{2} \mathrm{O}$ vapour phase; $\mathrm{L}, \mathrm{H}_{2} \mathrm{O}$ liquid phase. (b) At $15^{\circ} \mathrm{C}$ : $\mathrm{L}, \mathrm{CO}_{2}$ liquid phase; $\mathrm{V}, \mathrm{CO}_{2}$ vapour phase with characteristic highly diffracting (thick walled) vapour bubble. (c) At $\sim 4^{\circ} \mathrm{C}: \mathrm{L}_{\mathrm{w}}, \mathrm{H}_{2} \mathrm{O}$ rich liquid phase; $\mathrm{L}_{\mathrm{c}}, \mathrm{CO}_{2}$ rich liquid phase; $\mathrm{V}$, a mixed aqueous carbonic vapour phase (dominated by $\mathrm{CO}_{2}$ ). coeval groups (i.e. in individual crystals), but these can vary across coeval groups ( $\left.1.5 \quad 30 \mathrm{vol} \% \mathrm{CO}_{2}\right)$. Similar to the Type 2 fluid inclusions, the melting temperature of the $\mathrm{CO}_{2}$ is lowered ( 57 to $60^{\circ} \mathrm{C}$ ), indicating a similar gas contamination to that found in the Type 2 fluid inclusions (see above). The melting temperatures for ice in these inclusions correspond to salinities of $712 \mathrm{wt} \%$ $\mathrm{NaCl}$ equiv., which are significantly higher than those found in Type 1 fluid inclusions. This inclusion type, while coeval with Type 2 fluid inclusions, generally occurs in clusters and appears to represent an occurrence where the $\mathrm{H}_{2} \mathrm{O}$-rich and $\mathrm{CO}_{2}$-rich phases were trapped from a homogenous fluid.

No homogenisation data have been recorded for Type 3 inclusions, as they invariably decrepitate before reaching their minimum homogenisation temperature.

\section{Pressure-volume-temperature extrapolations}

In most studies, the temperature of trapping is estimated by using a pressure correction such as an estimated depth or coeval mineral phase in conjunction with the calculated density isochore (Wilkinson 2001 and references therein). This method is inexact due to errors in depth estimation and the fact that no mineral can be stated to be coeval with the fluid inclusion in question. In contrast, the current study employs a method first introduced by Nacken (1921), in which a pressure correction is not required. By plotting $P \quad V T$ diagrams for coeval $\mathrm{H}_{2} \mathrm{O}$ and $\mathrm{CO}_{2}$ systems in the same plane, the trapping pressure $\left(P_{\mathrm{t}}\right)$ and temperature $\left(T_{\mathrm{t}}\right)$ can be defined by the intersection of the $\mathrm{CO}_{2}$ and $\mathrm{H}_{2} \mathrm{O}$ isochors. As this method is only valid if the inclusion pairs are coeval, it is seldom used due to the rarity of this occurrence. However, due to the high number and concentration of Type 1 and 2 fluid inclusions, we employed this method, which indicates a range of 22 $26 \mathrm{MPa}$ and $180220^{\circ} \mathrm{C}$ during fluid trapping (Figure 15).

These $P \quad T$ data constrain the pressure of ore formation to between hydrostatic and lithostatic depths corresponding to the calculated trapping pressures (Figure 16). In most natural environments, the depth of mineralisation most likely resides between these limits. In calculating the hydrostatic depth, a density of $1 \mathrm{~g} / \mathrm{cm}^{3}$ was used (pure water) as recommended by Roedder (1984), while the lithostatic depth was calculated using an overlying density of $2.3 \mathrm{~g} / \mathrm{cm}^{3}$ as an average density of the overlying sedimentary rock (VandenBerg \& Stewart 1992). The pressure range indicated by trapping

Table 3 Summary of microthermometric data from fluid inclusions.

\begin{tabular}{|c|c|c|c|c|c|c|c|c|c|c|c|c|}
\hline \multirow{2}{*}{$\begin{array}{l}\text { Inclusion } \\
\text { type } \\
\text { Type } 1\end{array}$} & \multicolumn{2}{|c|}{$T_{\mathrm{m}}, \mathrm{CO}_{2}\left({ }^{\circ} \mathrm{C}\right)$} & \multicolumn{3}{|c|}{$T_{\mathrm{m}}$, ice $\left({ }^{\circ} \mathrm{C}\right)$} & \multirow[t]{2}{*}{$T_{\mathrm{h}}, \mathrm{CO}_{2}\left({ }^{\circ} \mathrm{C}\right)$} & \multicolumn{2}{|c|}{$T_{\mathrm{h}}, \mathrm{H}_{2} \mathrm{O}\left({ }^{\circ} \mathrm{C}\right)$} & \multicolumn{2}{|c|}{$\begin{array}{l}\text { Wt \% } \mathrm{NaCl} \\
\text { equivalent }\end{array}$} & \multirow{2}{*}{$\begin{array}{l}\mathrm{XCH}_{4}, \\
\text { liquid }\end{array}$} & $\begin{array}{l}\mathrm{XCH}_{4}, \\
\text { vapour }\end{array}$ \\
\hline & & & 5.8 to & 2.1( & 4.3) & & 157.4 & $334.2(236.1)$ & 4.3 & $8.9(6.9)$ & & \\
\hline Type 2 & 61.1 to & $57.0(59.0)$ & & & & $11.414 .4(12.0)$ & & & & & $(0.03)$ & $0.05 \quad 0.10$ \\
\hline Type 3 & 60.0 to & $57.2(58.0)$ & 7.1 to & 1.8( & 4.5) & $10.5 \quad 16.5$ (14.5) & & & 3.1 & $11.5(7.2)$ & & \\
\hline
\end{tabular}

Minimum and maximum values are shown with median values given in parentheses.

$T_{\mathrm{m}}, \mathrm{CO}_{2}$, final melting temperature of solid $\mathrm{CO}_{2} ; T_{\mathrm{m}}$, ice, final melting temperature of ice; $T_{\mathrm{h}}, \mathrm{CO}_{2}$, temperature of $\mathrm{CO}_{2}(\mathrm{~L}+\mathrm{V}) \Rightarrow \mathrm{CO}_{2}$ (L); $T_{\mathrm{h}}, \mathrm{H}_{2} \mathrm{O}$, temperature of $\mathrm{H}_{2} \mathrm{O}(\mathrm{L}+\mathrm{V}) \Rightarrow \mathrm{H}_{2} \mathrm{O}(\mathrm{L}) ; X \mathrm{CH}_{4}$, liquid, mole fraction of $\mathrm{CH}_{4}$ in the inclusion; $X \mathrm{CH}_{4}$, vapour, mole fraction of $\mathrm{CH}_{4}$ in the vapour phase. 


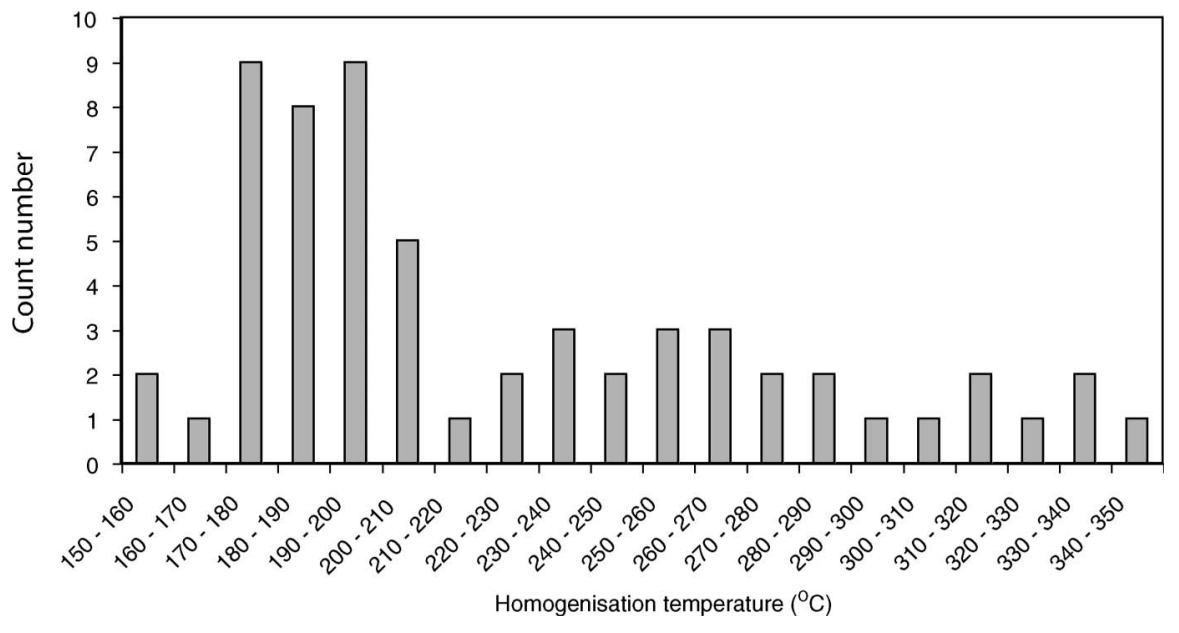

\section{P-T extrapolations}

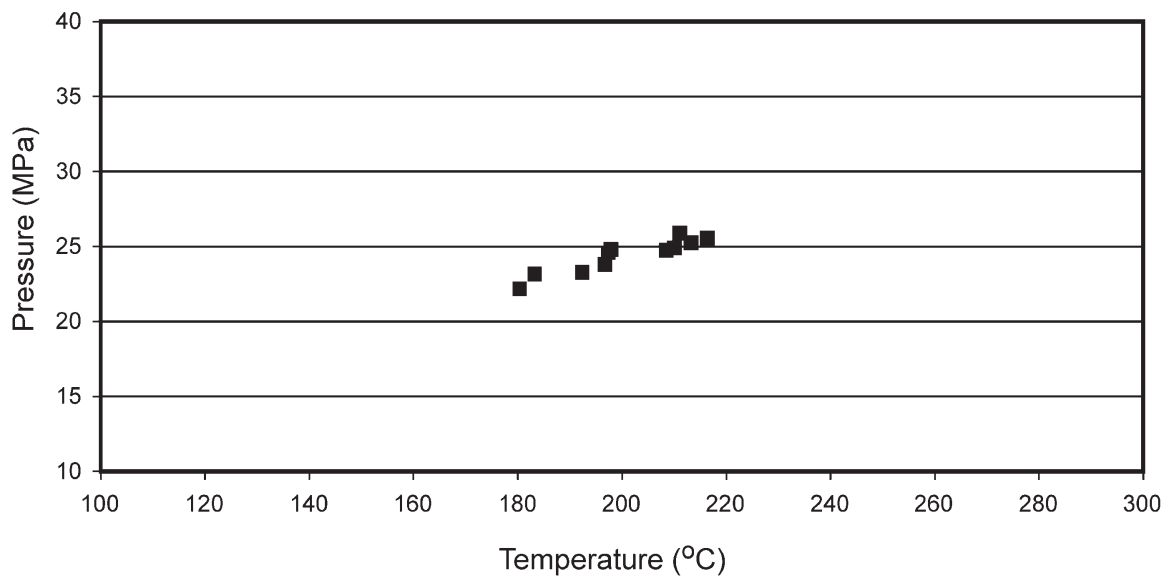

Depth of mineralisation

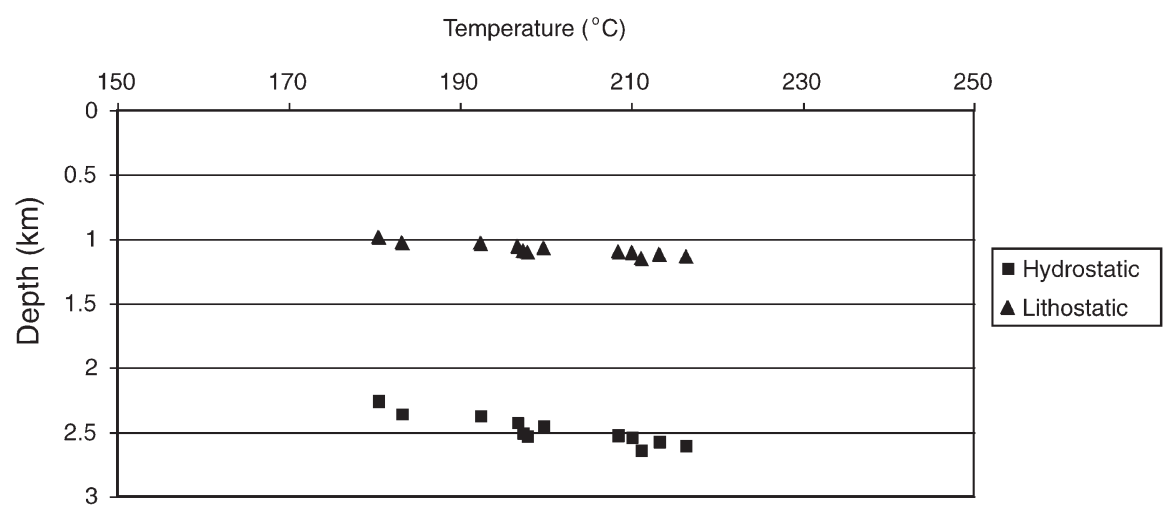

Figure 14 Temperature of homogenisation for the Type 1 fluid inclusion population. Homo genisation temperatures cover a wide range and vary from 155 to $350^{\circ} \mathrm{C}$, with a mode at $\sim 190^{\circ} \mathrm{C}$.

Figure $15 P \quad T$ data constrained by intersecting density isochors of coeval Types 1 and 2 fluid inclu sions. Intersection points indicate trapping conditions ranging from 22 to $26 \mathrm{MPa}$ and 180 to $220^{\circ} \mathrm{C}$.

Figure 16 Calculated depth $v$ s trap ping temperature, demonstrating the depth variance between litho static and hydrostatic pressure.

translates into a depth range of $\sim 1.1 \quad 2.5 \mathrm{~km}$ (Figure 16). This depth range corresponds with deep epithermal conditions (Evans 1993), which is supported by the presence of abundant open-space, elongated quartz crystals in vein specimens, indicating a low-pressure mineralising environment (Potter 1977). These depth estimates are also consistent with inferred shallow emplacement levels of Middle to Late Devonian intrusions throughout the western Lachlan Orogen (as evidenced by porphyritic and pressure quenching 
textures, and abundance of miarolitic cavities in most granites and dykes), as well as the removal of $\sim 510 \mathrm{~km}$ of the metasedimentary succession between the occurrence of peak metamorphism in the Bendigo Zone at around $450 \mathrm{Ma}$, and the onset of Devonian magmatism there (VandenBerg et al. 2000; Bierlein et al. 2001b; White 2002).

\section{Comparison of fluid characteristics}

The fluid-inclusion characteristics of quartz in the Leven Star deposit are distinct from those found in the Missing Link lode deposit (Malmsbury goldfield) in that primary fluid inclusions in the latter are $\mathrm{H}_{2} \mathrm{O} \quad \mathrm{CO}_{2}$-rich (i.e. Type 3 only). While $\mathrm{H}_{2} \mathrm{O}: \mathrm{CO}_{2}$ ratios vary throughout the fluid-inclusion population of the Missing Link lode, there is little evidence for Types 1 and 2, or Types 2 and 3 fluid inclusions occurring together.

Using the fluid-inclusion characteristics of quartz from the Leven Star deposit, the estimated temperature and depth of mineralisation can be compared with that found in orogenic gold deposits elsewhere in the western Lachlan Orogen (Figure 17). Classic orogenic quartzlode style deposits in the Bendigo and Stawell Zones were emplaced at depths $>5 \mathrm{~km}$ and at temperatures generally at $300^{\circ} \mathrm{C}$ or greater, whereas deposits at Fosterville, Nagambie, and Brunswick are inferred to have formed at depths between 1 and $5 \mathrm{~km}$ and at temperatures below $300^{\circ} \mathrm{C}$ (Gao \& Kwak 1995) (Figure 17). Notably, the style of mineralisation in the Leven Star deposit closely resembles disseminated-style, sandstonehosted gold deposits at Nagambie and Brunswick (Bierlein \& Maher 2001).

Volatile impurities in the carbonic phase of the mineralising fluid at Leven Star are dominated by $\mathrm{CH}_{4}$, with little evidence for $\mathrm{N}_{2}$ content. The depression of $T_{\mathrm{m}, \mathrm{CO} 2}$ (melting temperature of $\mathrm{CO}_{2}$ ice) in Type 2 fluid-inclusions values ( $57^{\circ} \mathrm{C}$ to $61.5^{\circ} \mathrm{C}$ ) indicates a high volatile content for the ore-forming fluids. In comparison with other similarly disseminatedstyle gold deposits in the Bendigo Zone (i.e. Fosterville, where $\mathrm{CO}_{2}$ melting temperatures range from $56^{\circ} \mathrm{C}$ to $57^{\circ} \mathrm{C}$ : Mernagh 2001), the volatile content in the mineralising fluid at Leven Star is higher and varies more widely.

\section{DISCUSSION}

\section{Genesis of the Leven Star deposit: structural considerations and timing relationships}

Due to a paucity of outcrop, little structural evidence is available to place the Leven Star deposit in a comprehensive structural regime. Unlike the vast majority of orogenic deposits in the Bendigo Zone, which are associated with north-northwest- to northwest-trending thrust faults and were emplaced under brittle ductile conditions during east west shortening, mineralisation at Malmsbury was emplaced in northeast-trending, extensional structures. The majority of stockwork veins are unrelated to the orientation of the shear zone and indicate hydraulic fracturing of the surrounding wall rock. The orientation of the linear shear zone that hosts the Leven Star deposit relative to orogenic, fault-hosted quartz lodes in the Malmsbury goldfield could reflect a north-northwest-plunging, conjugate fault system, with both the east-dipping orogenic quartz lodes and the west-dipping Leven Star deposit striking at an oblique angle to the north-northwest-trending fold hinges (Figure 2). Where the faults intersect a fold axial plane, the mineralised lodes develop an intermediate plunge, thus restricting the geometry at depth and causing the lodes to pinch out. This geometry could account for the atypical orientation of the Leven Star shear zone, and also explains why the lode structures are oblique to the fold axial planes (Figure 2). The occurrence of conjugate faulting has also been observed in other areas of the Bendigo Zone (VandenBerg et al. 2000). Thus, no firm conclusions can be made to the origin of the Leven Star shear zone on the basis of structural interpretations alone.
Figure 17 Trapping temperatures $v s$ depth of selected gold deposits in the western Lachlan Orogen (modified from Mernagh 2001). Data from Cox et al. (1995), Gao and Kwak (1995), Gao et al. (1995), Changkakoti et al. (1996), Li (1997), and Mernagh (2001).

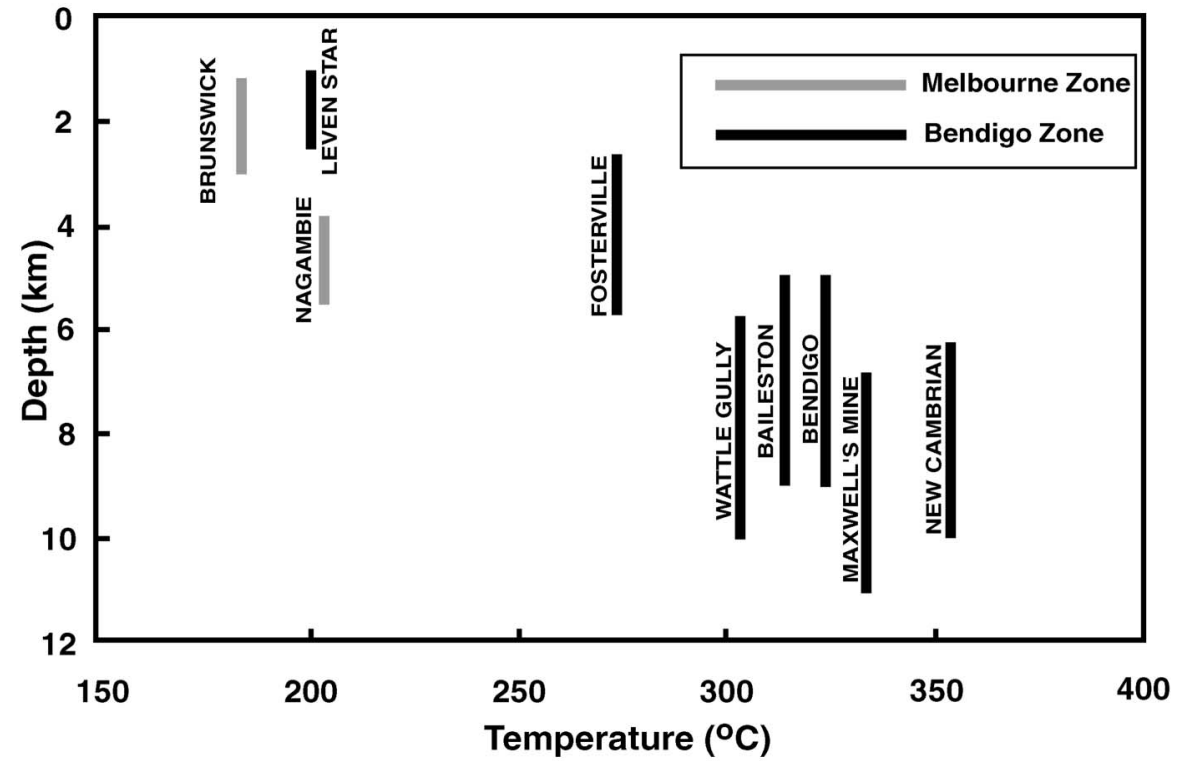


Felsic dykes have been observed in many orogenic gold deposits in the western Lachlan Orogen, and there is a common spatial relationship between orogenic lode gold deposits and major granitic intrusions (Bierlein et al. 2001a). Except for deposits at Fosterville and the easternmost portion of the Melbourne Zone, however, the vast majority of orogenic gold deposits are cut by these felsic dykes and pre-date the emplacement of spatially related granites by tens of millions of years. In contrast, the Leven Star deposit displays evidence for a local thermal event and, importantly, post-dates the emplacement of spatially associated intermediate to felsic dykes.

The available geochronological constraints suggest that mineralisation of Leven Star occurred at ca $370 \mathrm{Ma}$ (Bierlein \& McKnight 2005) and, as such, 80 million years after the main period of orogenic gold mineralisation in the western Lachlan Orogen ( $c$ a $440 \mathrm{Ma}$ ). The timing and synchroneity of ore formation at Leven Star and the emplacement of ca 370 Ma felsic intrusions are significant, as they indicate that the mineralising fluid was entirely unrelated to metamorphic orogenic processes in the Bendigo Zone, but rather provides data consistent with a magmatic genesis for gold mineralisation in the Leven Star deposit. However, it is unlikely that the felsic dykes in the Malmsbury goldfield can account for the genesis of the mineralising fluid, given their relatively limited volume and low abundance. Instead, it is conceivable that both the mineralising fluid and the felsic dykes originated from a common, but buried, magmatic source. As was pointed out by Bierlein and McKnight (2005), high-resolution total magnetic intensity imaging of the area around Malmsbury reveals a distinct negative anomaly beneath and to the west of the Leven Star deposit, and it is conceivable that this anomaly is the manifestation of an intrusive body.

\section{Constraints on the source of the ore-bearing fluid and mineral assemblage}

The occurrence of Type 3 inclusions, and coeval occurrence of Types 1,2 and 3 fluid inclusions in virtually all quartz veins in the Leven Star deposit, and no discernible spatial pattern or zonation, are indicative of extensive phase effervescence in the hydrothermal fluid during mineralisation. The distribution of homogenisation temperatures for Type 1 fluid inclusions also supports the occurrence of true boiling, where $\mathrm{H}_{2} \mathrm{O}$ vapour is trapped with $\mathrm{H}_{2} \mathrm{O}$ liquid during effervescence, artificially raising $T_{\mathrm{h}}$ (Wilkinson 2001). Thus, the fluid responsible for mineralisation at Leven Star likely evolved from a homogenous, aqueous carbonic fluid to a heterogeneous system that underwent periodic effervescence. The cogenetic nature of immiscible globules of $\mathrm{CO}_{2}\left( \pm \mathrm{CH}_{4}\right)$ in Type 2 inclusions with both Types 1 and 3 also indicates that the fluid was never truly homogeneous during mineralisation.

Evidence from fluid inclusions, and petrography of quartz and sulfides (Figures 10 12) suggest that deposition of gold was primarily controlled by hydraulic fracturing that caused pressure fluctuations in the hydrothermal system. This notion is supported by the brittle-dominated, stockworked nature of the quartz veins at Leven Star and their apparent lack of associa- tion with fault movement. Cyclical brecciation of both the wall rock and pre-existing veins is likely to have been primarily formed by hydraulic processes during exhumation, when continual addition of hydrothermal fluid to the system created a gradual rise in fluid pressure until the surrounding host rock was fractured, causing a sudden drop in fluid pore pressure and subsequent mineralisation of quartz, sulfides, and gold. This mineralisation model is evidenced by oscillatory chemical zoning of arsenopyrite in the Leven Star deposit.

The estimated $P \quad T$ conditions of Leven Star (22 26 $\mathrm{MPa}, 180220^{\circ} \mathrm{C}$ ) indicate that mineralisation occurred at relatively shallow depths. Such a shallow emplacement level, which is atypical of the majority of orogenic gold mineralisation throughout the western Lachlan Orogen, might be expected, given the late-stage timing of mineralisation at Leven Star relative to deformation and exhumation of the western Lachlan Orogen.

The complex $\mathrm{Au} \pm \mathrm{Bi} \mathrm{Te} \mathrm{Sb} \mathrm{Cu} \mathrm{Zn} \mathrm{Pb}$ Sn W assemblage observed in the Leven Star deposit (Table 2) is also atypical of the majority of orogenic gold mineralisation throughout the western Lachlan Orogen. Instead, we consider this polymetallic (albeit low-level) association indicative of a magmatic hydrothermal fluid, possibly sourced from a fractionating, cordierite and/or hornblende biotite-bearing granitic intrusion with a relatively low to intermediate oxidation state during Middle to Late Devonian magmatism in the central Victorian gold province (Baker \& Lang 2001; Bierlein et al. 2001b; Lang \& Baker 2001; White 2002). Such a genetic model, involving partitioning of these incompatible metals, along with $\mathrm{CO}_{2}$ and $\mathrm{H}_{2} \mathrm{O}$, into the late-stage metasomatic fluid phase (Crespo 1998; Diment \& Craig 1998; Baker 2002), is supported by the occurrence of temporally related felsic dykes and a possible buried major intrusion in the Malmsbury goldfield. Furthermore, the polymetallic signature and $P T$ conditions of ore formation in the Leven Star deposit suggest a genetic association with the $\mathrm{Au}$ Sb epizonal and polymetallic styles found in the Melbourne Zone (Bierlein et al. 2001b, 2002).

\section{Classification of the Leven Star deposit: orogenic-disseminated or intrusion-related style of mineralisation?}

Metamorphism-related (orogenic-lode and orogenicdisseminated style) gold deposits most closely mirror the characteristics of intrusion-related gold systems, in part because these deposit types form in comparable tectonic settings (Lang \& Baker 2001). Unsurprisingly, the style of gold mineralisation in the Leven Star deposit has similarities with orogenic-lode, orogenic-disseminated and intrusion-related gold deposits. Nonetheless, and although similarities in mineralisation style, fluid composition, generally low sulfide mineral concentrations, and alteration commonly render distinction between metamorphism-related orogenic and intrusion-related deposit types difficult, we can attempt to constrain the genesis of the Leven Star deposit by consideration of characteristic features typifying these deposit styles (Table 4). Although the formation of 
Table 4 Comparison of genetic models to Leven Star.

\begin{tabular}{|c|c|c|c|}
\hline & $\begin{array}{l}\text { Orogenic disseminated } \\
\text { (epizonal) gold }\end{array}$ & Intrusion related gold deposits & Leven Star \\
\hline Tectonic setting & $\begin{array}{l}\text { Convergent plate margins } \\
\text { (Orogenic associated) (1) }\end{array}$ & $\begin{array}{l}\text { Associated with collisional } \\
\text { belts, post tectonic ( } 7)\end{array}$ & $\begin{array}{l}\text { Occurred in a collisional belt, } \\
\text { during post orogenic extension }\end{array}$ \\
\hline Structural controls & $\begin{array}{l}\text { Associated with dilation zones } \\
\text { in reverse faults (breccia zones) } \\
\text { or fold related fractures (5) } \\
\text { Depth range: near surface to } \\
>20 \mathrm{~km} \text { (2) }\end{array}$ & $\begin{array}{l}\text { Major regional structures and } \\
\text { thrust related shortening (7) } \\
\text { Depth range: }<5 \mathrm{~km} \text { in } \\
\text { sediment or dyke hosted } \\
\text { disseminated gold deposits (8) }\end{array}$ & $\begin{array}{l}\text { Shear/breccia zone } \\
\text { Depth range: } \sim 125 \mathrm{~km} \text {, } \\
\text { shallow mesothermal to } \\
\text { epithermal conditions }\end{array}$ \\
\hline Host rock & $\begin{array}{l}\text { Occurs in weakly } \\
\text { metasandstones and siltstones, } \\
\text { peripheral to fault breccias (4) }\end{array}$ & $\begin{array}{l}\text { These sequences vary in } \\
\text { metamorphic grade; } \\
\text { subgreenschist upper } \\
\text { amphibolite and eclogite facies } \\
\text { (15) }\end{array}$ & $\begin{array}{l}\text { Sub greenschist meta } \\
\text { sandstones and pelites } \\
\text { Host rock relatively permeable }\end{array}$ \\
\hline Mineral assemblage & $\begin{array}{l}\text { Silicified wall rock, with } \\
\text { carbonate, sericite, chlorite, } \\
\text { tourmaline, with disseminated } \\
\text { pyrite, arsenopyrite, native } \\
\text { gold, and rare } \mathrm{Cu}, \mathrm{Pb}, \mathrm{Zn} \text {, and } \\
\text { Sb sulfides }(2,6)\end{array}$ & $\begin{array}{l}\text { Biotite and muscovite } \\
\text { alteration of host rock (7) } \\
\text { Common phases: pyrite, } \\
\text { arsenopyrite and pyrrhotite (7) } \\
\text { Lesser phases: loellingite, } \\
\text { maldonite, native Bi and } \\
\text { assorted Te Bi minerals (7) } \\
\text { Sb rich minerals common in } \\
\text { distal or high level deposits (7) }\end{array}$ & $\begin{array}{l}\text { Contact metamorphism: biotite } \\
\text { and cordierite } \\
\text { Metasomatism: recrystallised } \\
\text { calcite, dolomite, cassiterite, } \\
\text { scheelite, wolframite, } \\
\text { sphalerite, galena, Bi Te } \\
\text { phases, monazite } \\
\text { Hydrothermal: dominated } \\
\text { by sericite, carbonate, } \\
\text { pyrite, arsenopyrite, } \\
\text { stibnite }\end{array}$ \\
\hline Fluid properties & $\begin{array}{l}\mathrm{CO}_{2} \text { bearing, low salinity } \\
1 \quad 10 \mathrm{wt} \% \mathrm{NaCl}_{\text {eq }}(6) \\
\text { Temperature range: typically } \\
275350^{\circ} \mathrm{C}(3)\end{array}$ & $\begin{array}{l}\text { High } \mathrm{CO}_{2}, 3 \quad 11 \% \text { salinity } \\
(13,14) \\
\text { Hydraulic fracturing } \\
\text { and boiling common }(9) \\
\text { Temperature range: } \\
\sim 200 \quad 600^{\circ} \mathrm{C}(8,12)\end{array}$ & $\begin{array}{l}\mathrm{CO}_{2} \text { rich fluid with a salinity } \\
\text { range of } 49 \% \\
\text { Episodic hydraulic fracturing } \\
\text { and effervescence } \\
\text { Temperature range: } 180220^{\circ} \mathrm{C}\end{array}$ \\
\hline Typical fluid alteration & $\begin{array}{l}\text { Chloritisation, carbonisation, } \\
\text { sulfidation and sericitisation } \\
(2,3)\end{array}$ & $\begin{array}{l}\text { Early: feldspar alteration } \\
\text { (high temperature deposits) } \\
\text { and biotite alteration ( } 7 \text { ) } \\
\text { Late: hydrothermal } \\
\text { sericite carbonate sulfide } \\
\text { alteration (7) }\end{array}$ & $\begin{array}{l}\text { Early: biotite cordierite } \\
\text { contact metamorphism } \\
\text { Late: metasomatic assemblage } \\
\text { overprinted hydrothermal } \\
\text { sericite carbonate sulphide } \\
\text { alteration }\end{array}$ \\
\hline $\begin{array}{l}\text { Style of mineralisation } \\
\text { and veining }\end{array}$ & $\begin{array}{l}\text { Thin quartz carbonate veinlets } \\
\text { occur in the host rock as; } \\
\text { bedding parallel or concordant } \\
\text { veins, discordant veins, saddle } \\
\text { reefs and stockwork veins (5) } \\
\text { Gold occurs as } 110 \mu \mathrm{m} \\
\text { diameter blebs in fine grained } \\
\text { ( }>1 \mathrm{~mm} \text { ) disseminated } \\
\text { arsenopyrite and pyrite in host } \\
\text { rock (5) }\end{array}$ & $\begin{array}{l}\text { Variety of vein styles; } \\
\text { stockwork and sheeted the } \\
\text { most common }(7,12) \\
\text { Gold generally appears in } \\
\text { host rock similar to orogenic } \\
\text { disseminated style }(7)\end{array}$ & $\begin{array}{l}\text { Vein style is stockworked } \\
\text { Gold found as a solid solution } \\
\text { in arsenopyrite grains }\end{array}$ \\
\hline$P \quad T$ conditions & $\begin{array}{l}\text { Post peak regional } \\
\text { metamorphic conditions (1) } \\
250 \quad 400^{\circ} \mathrm{C} \text { and } 100 \quad 300 \mathrm{MPa}(1)\end{array}$ & $\begin{array}{l}\sim 200^{\circ} \mathrm{C} \text { to more than } 600^{\circ} \mathrm{C} \\
<150 \mathrm{MPa}(10)\end{array}$ & $\begin{array}{l}\text { Contact metamorphism: } \\
\sim 350 \quad 450^{\circ} \mathrm{C} \\
\text { Hydrothermal conditions: } \\
180 \quad 220^{\circ} \mathrm{C} \text { and } 22 \quad 26 \mathrm{MPa}\end{array}$ \\
\hline Geochemical trends & $\begin{array}{l}\text { Enrichment: } \mathrm{CO}_{2}, \mathrm{H}_{2} \mathrm{O}, \mathrm{K}_{2} \mathrm{O}, \mathrm{S} \\
\mathrm{As}, \mathrm{Au} \pm \mathrm{Sb}(3) \\
\text { Decrease: } \mathrm{Na}_{2} \mathrm{O}(3) \\
\mathrm{Au} \text { correlates well with } \mathrm{S} \\
\mathrm{As} \pm \mathrm{Sb}(2)\end{array}$ & $\begin{array}{l}\text { Enrichment: } \mathrm{Au} \text { As } \mathrm{Sb} \pm \mathrm{Bi} \text {, } \\
\mathrm{Te}, \mathrm{Cu}, \mathrm{Zn}, \mathrm{Pb}, \mathrm{Mo} \\
\mathrm{Sn}, \mathrm{W}, \mathrm{Hg} \text { and } \mathrm{Ag}(7,11,12)\end{array}$ & $\begin{array}{l}\text { Enrichment: } \mathrm{Au} \mathrm{As} \mathrm{Sb} \\
(\mathrm{Zn}) \pm \mathrm{Bi}, \mathrm{Te}, \mathrm{Cu}, \mathrm{Pb}, \mathrm{Sn} \text { and } \mathrm{W} \\
\text { Decrease: } \mathrm{Na}_{2} \mathrm{O} \\
\mathrm{Au} \text { correlates well with } \mathrm{As}, \\
\mathrm{S} \text { and } \mathrm{Sb}\end{array}$ \\
\hline
\end{tabular}

References: 1, Bierlein and Crowe (2000); 2, Groves et al. (1998); 3, Bierlein et al. (2000); 4, McKnight et al. (1998); 5, Christie et al. (2000); 6, Bierlein and Maher (2001); 7, Thompson and Newberry (2000); 8, Baker (2002); 9, Lang et al. (2000); 10, McCoy et al. (1997); 11, Thompson et al. (1999); 12, Lang and Baker (2001); 13, Spiridonov (1996); 14, Yao et al. (1999); 15, Hart et al. (2000). 
orogenic lode gold mineralisation in the Malmsbury goldfield is evident in nearby fault structures (Panama and Missing Link lodes: Figure 2), we consider metamorphism-related (orogenic) deposition unlikely for the formation of the Leven Star deposit, based on available timing constraints, alteration characteristics and mineralisation style. The absence of major quartz lodes, and the finely disseminated occurrence of gold in the wall rock, further indicate that the Leven Star deposit is genetically more closely related to either orogenic disseminated (epizonal) or shallow, distal/proximal intrusion-related gold mineralisation styles.

Table 4 illustrates the difficulty of a definitive distinction between an orogenic disseminated (epizonal) and intrusion-related origin for the Leven Star deposit. However, the close spatial and temporal association with major plutons and felsic dykes, coexistence with, but post-dating the emplacement of orogenic gold mineralisation, a complex mineral paragenesis and polymetallic ore assemblage, whole-rock geochemistry, features of alteration and fluid-inclusion data presented here all suggest that the Leven Star deposit, while not a classic 'intrusion-hosted intrusionrelated gold system' (as defined by Thompson \& Newberry 2000), resulted from the evolution of magmatic fluids produced by residual melts during Middle Late Devonian magmatism. The mineralisation style and geochemistry, and lack of a major outcropping granitic body, might indicate that mineralisation in the Leven Star deposit is in a relatively distal position from the source intrusion, not dissimilar in style and position to intrusion-related gold deposits at Keno Hill and Brewery Creek in the Yukon (Lynch et al. 1990; Diment \& Craig 1998), Donlin Creek and True North in Alaska (Ebert et al. 2000; Goldfarb et al. 2004) and Niuxinshan in northern China (Miller et al. 1998). On the other hand, there is strong evidence for a thermal (contact metamorphic) overprint of the regional low-grade metamorphism at Leven Star that is unlikely to be the result of the emplacement of felsic dykes of rather limited extent. Although the exact source of this thermal overprint remains geologically unconstrained, as mentioned earlier, the possible presence of a subsurface intrusive body beneath the Leven Star deposit has been indicated recently by means of geophysical exploration methods (Bierlein \& McKnight 2005). The presence of such an intrusion underneath the Leven Star deposit could account for the localised occurrence of thermal metamorphism in an area well beyond the limit of the contact aureole of the Harcourt Batholith to the north $(7.2 \mathrm{~km})$ and the outer ring pluton of the Cobaw Batholith to the east (10 km).

\section{CONCLUSIONS}

Field evidence, petrographic observations, geochemical characteristics, a polymetallic $\mathrm{Au}$ As $\mathrm{Sb}( \pm \mathrm{Bi}$ $\mathrm{Te} \mathrm{Cu} \mathrm{Zn} \mathrm{Pb} \mathrm{Sn}$ W) association, and geochronological constraints support a model where gold mineralisation in the Leven Star deposit resulted from a magmatic hydrothermal fluid associated with Middle to Late Devonian magmatism in the central Victorian gold province.

Constraints from fluid inclusions point to a fractionating granitic body as the source for the fluid responsible for mineralisation at Leven Star, with ore formation closely related to pressure decrease and phase separation. The Leven Star deposit does not resemble the orogenic style of gold deposit typical of the Bendigo and Stawell Zones but displays many features common to intrusion-related gold deposits linked to reduced granitoids and most closely resembles the $\mathrm{Au} \mathrm{Sb}$ epizonal style and polymetallic style of gold mineralisation that dominate the Melbourne Zone.

\section{ACKNOWLEDGEMENTS}

We gratefully acknowledge support for this study from Geoscience Victoria (especially P. O'Shea, S. Maher and A. Radojkovic). B. van Riel is thanked for access to the study area, field support and provision of drillcore samples. The work presented herein benefited from input from R. Mustard and D. Arne, and thorough formal reviews by T. Baker and G. Mark. FPB acknowledges support from a Monash University Logan Research Fellowship and a University of Western Australia Research Fellowship.

\section{REFERENCES}

Ashley P. M., CREAGH C. J. \& RyAN C. G. 1999. Invisible gold in ore and mineral concentrates from the Hillgrove gold antimony deposits, NSW, Australia. Mineralium Deposita 35, 285301.

BAKER T. 2002. Emplacement depth and carbon dioxide rich fluid inclusions in intrusion related gold deposits. Economic Geology 97, 11111117.

BAKER T. \& LANG J. R. 2001. Fluid inclusion characteristics of intrusion related gold mineralization, Tombstone tungsten mag matic belt, Yukon Territory, Canada. Mineralium Deposita 36 563582.

BAKKER R. J. 2003. FLUIDS 1. Computer programs for analysis of fluid inclusion data and for modelling bulk fluid properties. Chemical Geology 194, 3 23. Online <http://www.unileoben. ac.at/ buero62/minpet/Bakker/Programs/Computer.html>

Bierlein F. P., ARne D. C., KeAy S. M. \& MCNAughton N. J. 2001b. Timing relationships between felsic magmatism and mineralisation in the central Victorian gold province, southeast Australia. Australian Journal of Earth Sciences 48, 883899.

Bierlein F. P., Arne D. C., McKnight S., Lu J., Reeves S., BESANKO J., MAREK J. \& COOKE D. 2000. Wallrock petrology and geochemistry in alteration haloes associated with mesothermal gold mineralization, central Victoria, Australia. Economic Geo logy 95, 283312.

Bierlein F. P. \& Crowe D. E. 2000. Phanerozoic orogenic lode gold deposits. SEG Reviews 13, 103139.

Bierlein F. P., Gray D. R. \& Foster D. A. 2002. Metallogenic relationships to tectonic evolution the Lachlan Orogen, Australia. Earth and Planetary Science Letters 202, 113.

Bierlein F. P., Hughes M., DunPHy J., MCKNIGHT S., REYNOLDS P. R. \& WALDRON H. M. 2001a. Trace element geochemistry, ${ }^{40} \mathrm{Ar} /{ }^{39} \mathrm{Ar}$ ages, Sm Nd systematics and tectonic implications of mafic intermediate dykes associated with orogenic lode gold miner alisation in central Victoria, Australia. Lithos 58, 131.

BIERLEIN F. P. \& MAHER S. 2001. Orogenic disseminated gold in Phanerozoic fold belts examples from Victoria, Australia and elsewhere. Ore Geology Reviews 18, 113148. 
BIERLEIN F. P. \& MCKNIGHT S. 2005. Geology and genesis of intrusion related gold systems in the Western Lachlan Orogen, SE Australia. Economic Geology 100, 385398.

BuRRUSS R. C. 1981. Analysis of fluid inclusions: phase equilibria at constant volume. American Journal of Science 281, 11041126.

Changkakoti A., Gao Z., Green N., Kwak T. A. P., Gray J. \& Krouse H. R. 1996. Contrasting origins of $\mathrm{Au}$ and $\mathrm{Sb}$ bearing fluids, Central Victoria, Australia. Neues Jahrbuch für Miner alogie Monatshefte 6, 271285.

Chappell B. W., White A. J. R. \& Hine R. 1988. Granite provinces and basement terranes in the Lachlan Fold Belt, south eastern Australia. Australian Journal of Earth Sciences 35, 505524.

Christie A. B., CoRner N. G., Bierlein F. P., SMith P. K., RyAn R. J. \& ARNE D. C. 2000. Disseminated gold at Reefton, South Island, New Zealand, compared with similar occurrences in Victoria, Australia and Nova Scotia, Canada. New Zealand Mining 28, 2535.

Cox S. F., Sun S S., Etheridge M. A., WALl V. J. \& PotTer T. F. 1995. Structural and geochemical controls on the development of turbidite hosted gold quartz vein deposits, Wattle Gully Mine, central Victoria, Australia. Economic Geology 90, 17221746.

CRESPO J. 1998. The Salamon gold project, Leon, Spain. In: Arias D., Martin Izard A. \& Paniagua A. eds. International Meeting on Gold Exploration and Mining in NW Spain, pp. 86 95. Facultad de Geologia, Universidad de Oviedo, Oviedo.

DEER W. A., Howie R. A. \& Zussman J. 1992. An Introduction to The Rock Forming Minerals (2nd edition). Longman, Harlow.

DimenT R. \& CRAIG S. 1998. Brewery Creek gold deposit, central Yukon. In: Roots C. F. \& Emond D. S. eds. Yukon Exploration and Geology 1998, pp. 225 230. Exploration and Geological Services Division, Yukon Region, Indian and Northern Affairs Canada.

DonNelLy H. G. \& KATZ D. L. 1954. Phase equilibria in the carbon dioxide methane system. Journal of Engineering and Chemistry 46, 511517.

Duller P. R., Gallagher M. J., Hall A. J. \& Russell M. J. 1997. Glendinning deposit an example of turbidite hosted arsenic antimony gold mineralization in the southern Uplands, Scotland. Transactions of the Institution of Mining and Metal lurgy, Section B, Applied Earth Sciences 106, B119 B134.

Ebert S., Miller L., Petsel S., Dodd S. \& Kowalczyk P. 2000. Geology, mineralization, and exploration at the Donlin Creek project, southwestern Alaska. In: Tucker T. L. \& Smith M. T. eds. The Tintina Gold Belt: Concepts, Exploration and Discoveries, pp. 99 114. British Columbia and Yukon Chamber of Mines Special Publication 2.

EBsworth G. B., DE Vickerod Krokowski J. \& FothergiLl J. 1998. Eaglehawk Linscotts reef gold deposits, Maldon. In: Berkman D. A. \& Mackenzie D. H. eds. Geology of Australian and Papua New Guinean Mineral Deposits, pp. 527 533. Australasian Institute of Mining and Metallurgy Monograph 22

Evans A. M. 1993. Ore Geology and Industrial Minerals: An Introduction (3rd edition). Blackwell Science, Oxford.

Foster D. R. \& GRAY D. R. 2000. Evolution and structure of the Lachlan Fold Belt (Orogen) of eastern Australia. Annual Review of Earth and Planetary Sciences 28, 4780.

Foster D. A., Gray D. R. \& Bucher M. 1999. Chronology of deformation within the turbidite dominated, Lachlan orogen: implications for the tectonic evolution of eastern Australia and Gondwana. Tectonics 18, 452485.

Foster D. A., Gray D. R., KwaK T. A. P. \& Bucher M. 1998. Chronology and tectonic framework of turbidite hosted gold deposits in the Western Lachlan Fold belt, Victoria: ${ }^{40} \mathrm{Ar} /{ }^{39} \mathrm{Ar}$ results. Ore Geology Reviews 13, 229250.

GAO Z. L. \& KWAK T. A. P. 1995. Turbidite hosted gold deposits in the Bendigo Ballarat and Melbourne Zones, Australia. II. Nature of ore fluids. International Geology Reviews 37, 1007 1038.

GaO Z. L., Kwak T. A. P., Changkakoti A. \& Hussein E. 1995. Supergene ore and hypogene non ore mineralisation at Nagam bie sediment hosted gold deposit, Victoria, Australia. Economic Geology 90, 17471763

Genkin A. D., Bortnikov N. S., CABri L. J., WAgner F. E., Stanley C. J., Safonov Y. G., McMahon G., Friedl J., Kerzin A. L. \& GAMYANIN G. N. 1998. A multidisciplinary study of invisible gold in arsenopyrite from four mesothermal gold deposits in Siberia, Russian Federation. Economic Geology 93, 463487.
Goldfarb R. J., Ayuso R., Miller M. L., Ebert S. W., Marsh E. E., Petsel S. A., Miller L. D., Bradley D., Johnston C. \& MCClELLAND W. 2004. The Late Cretaceous Donlin Creek deposit, southwestern Alaska controls on epizonal formation. Economic Geology 99, 643671.

GRAY D. R. 1997. Tectonics of the South eastern Australian Lachlan Fold Belt: structural and thermal aspects. In: Burg J. P. \& Ford M. eds. Orogeny Through Time, pp. 149 177. Geological Society of London Special Publication 121.

Groves D. I., Goldfarb R. J., Gebre Mariam M., Hagemann S. G. \& ROBERT F. 1998. Orogenic gold deposits: a proposed classification in the context of their crustal distribution and relationship to other gold deposit types. Ore Geology Reviews 13, 727.

HART C. J. R., BAKER T. \& BURKE M. 2000. New exploration concepts for country rock hosted, intrusion related gold systems: Tintina gold belt in Yukon. In: Tucker T. L. \& Smith M. T. eds. The Tintina Gold Belt: Concepts, Exploration and Discoveries, pp. 145 172. British Columbia and Yukon Chamber of Mines Special Publication 2.

LANG J. R. \& BAKER T. 2001. Intrusion related gold systems: the present level of understanding. Mineralium Deposita 36, 477489.

Lang J. R., Baker T., Hart C. J. R. \& Mortensen J. K. 2000. An exploration model for intrusion related gold systems. Society of Economic Geologists Newsletter 40, 715.

LI X. 1997. Vein system and its fluid inclusion geochemistry in the Bendigo gold ore field: implications for ore fluid evolution. Geological Society of Australia Abstracts 46, 29.

Lynch G. J. V., Longstaffe F. J. \& Nesbitt B. E. 1990. Stable isotopic and fluid inclusion indicators of large scale hydrother mal paleo flow, boiling and fluid mixing in the Keno Hill Ag $\mathrm{Pb} \mathrm{Zn}$ district, Yukon Territory, Canada. Geochimica and Cosmochimica Acta 54, 10451059.

MAPANi B. E. S. \& Wilson C. J. L. 1998. Evidence for externally derived vein forming and mineralising fluids: an example from the Magdala gold mine, Stawell, Victoria, Australia. Ore Geology Reviews 13, 323343.

McCoy D. T., NeWBerRy R. J., LAYer P. W., DiMARChi J. J, BAKKe A., MASTERMAN J. S. \& Minehane D. L. 1997. Plutonic related gold deposits of interior Alaska. In: Goldfarb R. J. \& Miller L. D. eds. Ore Deposits of Alaska, pp. 151 190. Society of Economic Geologists Monograph 9.

McKnight S. \& VAN RIEL B. 2001. The Belltopper Hill (Leven Star) Prospect, Central Victoria. Australian Institute of Geoscientists Bulletin 34, 4751.

McKnight S., van Riel B., Cox B. \& MecCA R. 1998. Exploring for disseminated gold at Yea, Victoria. Australian Institute of Geoscientists Bulletin 24, 99106.

MERnaGh T. P. 2001. A fluid inclusion study of the Fosterville Mine: a turbidite hosted gold field in the Western Lachlan Fold Belt, Victoria, Australia. Chemical Geology 173, 91106.

Miller L. D., Goldfarb R. J., Nie F. J., Hart C. J. R., Miller M. L., YANG Y. \& LIU Y. 1998. North China gold a product of multiple orogens. Society of Economic Geologists Newsletter 33, 1,612 .

MoRAND V. J. 1994. Geological note: Calc silicate lenses in the Early Palaeozoic mud pile of the Lachlan Fold Belt. Australian Journal of Earth Sciences 41, 383386.

NACKEN R. 1921. Welche Folgerungen ergeben sich aus dem Auftreten von Flüssigkeitseinschlussen in Mineralien? Zentral blatt für Mineralogie 279, 12 20, 3543.

Phillips N. G. \& Hughes M. J. 1996. The geology and gold deposits of the Victorian gold province. Ore Geology Reviews 11, 255302.

PotTeR R. W. 1977. Pressure corrections for fluid inclusion homo genisation temperatures based on the volumetric properties of the system $\mathrm{NaCl} \mathrm{H}_{2} \mathrm{O}$. US Geological Survey Journal of Research 5,603607 .

RoEDDER E. 1984. Fluid Inclusions. Mineralogical Society of America Reviews in Mineralogy 12

SPIRIDONOV E. M. 1996. Granitic rocks and gold mineralization of North Kazakhstan. In: Shatov V., Seltmann R., Kremenetsky A., Lehmann B., Popov V. \& Ermolov P. eds. Granite Related Ore Deposits of Central Kazakhstan and Adjacent Areas, pp. 197217. Glagol Publishing House, St. Petersburg.

Thompson J. F. H. \& NewBerRY R. J. 2000. Gold deposits related to reduced granitic intrusions. Reviews in Economic Geology 13, 377400 . 
Thompson J. F. H., Sillitoe R. H., BAKer T., LANG J. R. \& MORTENSEN J. K. 1999. Intrusion-related gold deposits associated with tungsten - tin provinces. Mineralium Deposita 34, 323-334.

VANDENBERG A. H. M. \& STEWART I. R. 1992. Ordovician terranes of the southeastern Lachlan Fold Belt: stratigraphy, structure and palaeogeographic reconstruction. Tectonophysics 214, 159-176.

VANDENBERG A. H. M., Willman C. E. \& MAHER S. 2000. The Tasman Fold Belt System in Victoria: geology and mineralisation of Proterozoic to Carboniferous rocks. Geological Survey of Victoria Special Publication.

White A. J. R. 2002. Central Victorian granites-low oxidation states, near-surface intrusions and possible sources of salt. In: Phillips G. N. \& Ely K. eds. Victoria undercover-Benalla 2002 Conference Proceedings and Field Guide, pp. 51-53. CSIRO Publishing, Clayton.
WiLKINSON J. J. 2001. Fluid inclusions in hydrothermal ore deposits. Lithos 55, 229-272.

Yao Y., Morteani G. \& Trumbull R. B. 1999. Fluid inclusion microthermometry and the $P-T$ evolution of goldbearing hydrothermal fluids in the Niuxinshan gold deposit, eastern Hebei province, NE China. Mineralium Deposita 34 $348-365$. 